\title{
Multivariate statistical assessment of functional relationships between soil physical descriptors and structural features of soil organic matter in Mediterranean ecosystems
}

Lorena Recio-Vazquez ${ }^{1 *}$, Gonzalo Almendros ${ }^{1}$, Heike Knicker ${ }^{2}$, Pilar Carral ${ }^{3}$, AnaMaría Álvarez ${ }^{3}$

\footnotetext{
${ }^{1}$ National Museum of Natural Sciences (CSIC), Serrano 115B, 28006 Madrid, Spain.

${ }^{2}$ Institute for Natural Resources and Agrobiology (CSIC), Reina Mercedes 10, 41012 Seville, Spain.

${ }^{3}$ Department of Geology and Geochemistry, Faculty of Sciences, Universidad Autónoma de Madrid, Cantoblanco, 28049 Madrid, Spain.

* Corresponding author at: Department of Environmental Biology, National Museum of Natural Sciences (CSIC), Serrano 115b, 28006, Madrid (Spain). Phone: +34 917452500 (ext. 984121); e-mail address: lorena.recio.vazquez@gmail.com
}

\section{INTRODUCTION}

Monitoring soil quality is an essential step for preventing degradation processes frequently associated to intensive or inappropriate management of the soil resource. The concept of soil quality has been revised in recent years from a functional perception, being defined as the continued capacity of the soil to sustain biological productivity, preserve the quality of air and water and maintain biological activity within ecosystem boundaries (Larson and Pierce, 1991; Doran et al., 1996). This definition emphasises the value of the soil to perform specific functions. As a result, increasing attention has been paid on the exploration of soil variables which could be readily used as soil indicators (Arshad and Coen, 1992; Doran and Parkin, 1994; Powers et al., 1998; Reynolds et al., 2002). These indicators could be divided into chemical (e.g., pH, salinity, concentration of available nutrients, pollutants), physical (e.g., water retention, hydraulic conductivity, bulk density, stability of aggregates) and biological properties (e.g., microbial populations, mineralisation rates...) (Haynes, 2005). Most of these 
parameters are in close connection with soil organic matter (SOM), which represents a key factor in the maintenance of the soil quality (Gregorich et al., 1994).

Furthermore, in the Mediterranean region, the loss of soil quality is of special concern due to the particular fragility of these ecosystems. Soils developed in Central Spain are characterized by a large range of parent materials, landforms, plant communities and seasonal water regimes but, at the same time, show a series of common features such as shallow horizons, unfavourable physical conditions (limited water availability, hardened horizons, poor soil structure, etc.) and vulnerability to soil erosion due to irregular and frequently intensive precipitation (Rodeghiero et al., 2011) making water availability one of the most important limiting factors.

The climate largely influences the biological activity, leading to relatively low total organic C (TOC) concentrations in the Mediterranean regions (Rodríguez-Murillo, 2001) and consequently poor soil quality. In this line, the present study tackles the assessment of the quality of different Mediterranean soils - with special attention paid to physical status - by monitoring a set of quality indicators (bulk density, porosity, aggregate stability, available water capacity, etc.). Furthermore, the study of the distribution of organic $\mathrm{C}$ among different pools allows recognising soil features particularly affected by definite SOM fractions (i.e., particulate, extractable humic substances, humin...). On further examination, solid-state ${ }^{13} \mathrm{C}$ nuclear magnetic resonance (NMR), visible and infrared (IR) spectroscopies were applied to demineralised soil samples and to laboratory-isolated humic acids (HAs), allowing qualitative identification of its structural components, and results described comparatively.

Bearing in mind the importance of SOM on soil quality and the peculiarities of the Mediterranean scenario, this research focuses on establishing correlations between soil physical attributes and the SOM in order to assess the extent to which SOM characteristics work as valid predictors in forecasting the physical response in the soils. This exploratory research would lead to establish the basis for the proper selection of organic amendments whose addition to the soil could represent an effective management strategy against degradation processes in Mediterranean areas. 


\section{MATERIALS AND METHODS}

\subsection{Soil sampling sites}

Soil samples from fourteen Mediterranean ecosystems with marked continental features in Central Spain were collected. The study area comprises different locations of Madrid and Castilla-La Mancha and lies in the Inner Plateau (Meseta Central) of the Iberian Peninsula. Soils are developed on different geological substrates with altitudinal ranges between 470-2030 m a.s.1. (Table 1). The mountain landscapes are dominated by acid parental material (granites, gneisses and schists). The foothills areas exhibit detrital sedimentary rocks (arkoses), and the valley regions are defined by characteristic landforms of sedimentary basins (fluvial terraces, alluvial plains, moorlands, etc.) mainly composed of limestone, dolomite, gypsum, etc. The climate is Mediterraneantype with large winter-to-summer temperature contrast and pronounced summer droughts, when the water balance is strongly deficient ( 80 to $400 \mathrm{~mm}$ ). Moreover, unreliable and torrential precipitations are frequent (AEMET, 2013). The soils also differed in terms of vegetation (reforested pine tree forest, seminatural evergreen oak forest, Mediterranean brushwood, herbaceous vegetation, etc.) and land use (forestry, agricultural, livestock, abandoned lands, etc.). Table 1 summarises the location and main soil-forming factors in the studied areas as well as the different soil types: Kastanozems, Luvisols, Calcisols, Vertisols, Cambisols, Leptosols and Histosols (IUSSWRB, 2007) (Table 1 and Figure 1).

\subsection{Sample collection and analytical procedures}

After removing the litter, and for representative field sampling, soil material was collected from the uppermost organo-mineral horizon (i.e., in which the SOM was physico-chemically interacting with the soil mineral matrix). Composite soil samples were prepared by mixing the soil material (ca. $500 \mathrm{~g}$ ) from three spatial replicates separated about $10 \mathrm{~m}$ in each site. Samples were air-dried at room temperature and sieved to $2 \mathrm{~mm}$ to obtain the fine earth fraction.

Soil colour was determined in moist and dry samples by comparing with the Munsell (1975) colour sheets. Soil $\mathrm{pH}$ and electrical conductivity were measured in soil/water suspensions (1:2.5, w:w and 1:5 w:w, respectively) (Chapman and Pratt, 1961; Bower and Wilcox, 1965). Considering the large carbonate content in several of the soils under 
study, the Walkley and Black (1934) method based on wet oxidation in acid medium, was used to determine the concentration of TOC in soil, whereas the Kjeldahl's method was applied for nitrogen analysis according to Piper (1950). Carbonate content was measured as calcium carbonate with the Bernard's calcimeter (Guitián and Carballas, 1976). Soil active carbonate was also determined with the Bernard's calcimeter, after pre-treatment of $2.5 \mathrm{~g}$ soil samples with $0.2 \mathrm{M}$ ammonium oxalate for $2 \mathrm{~h}$ in a rotary agitator (Drouineau, 1942). The cation exchange capacity was determined with ammonium acetate solution at $\mathrm{pH} 7$ (Hendershot and Duquette,1986), and the ammonium concentration was titrated with a selective ion electrode. Exchangeable bases $\left(\mathrm{Ca}^{2+}, \mathrm{Mg}^{2+}, \mathrm{Na}^{+}\right.$and $\left.\mathrm{K}^{+}\right)$were extracted with $1 \mathrm{M}$ ammonium acetate $(\mathrm{pH} 7)$ and measured by inductively coupled plasma-atomic emission spectroscopy. Base saturation was calculated from the total exchangeable bases and the cation exchange capacity. Soil bulk density was determined using a cylindrical core of known volume (Blake and Hartge, 1986) and soil particle density was measured with a pycnometer. Soil porosity was calculated from the values of bulk density and soil particle density. Soil texture was determined with the densimeter method (Bouyoucos, 1927) after removing the SOM with $0.5 M$ hydrogen peroxide and soil dispersion for $16 \mathrm{~h}$ in a solution of $0.5 \mathrm{M}$ sodium hexametaphosphate and sodium carbonate. The water retention values of the soils were measured at the field capacity $(\mathrm{FC},-0.03 \mathrm{MPa})$ and at the permanent wilting point (PWP, $-1.5 \mathrm{MPa}$ ) using a pressure plate apparatus. Available water capacity (AWC) was calculated as the difference between FC and PWP (Guitián and Carballas, 1976). From these measurements, it was also possible to estimate the volume of air stored in the soil at some standardised value of soil water content or matric potential. In this case, this was done at the FC water content by the equation: 100 - (FC / P), where the water content at FC was expressed in volumetric units, and P represented the total porosity of the soil. The resulting air-filled porosity was referred to as field air capacity, FAC (Topp et al., 1997). To measure soil structural stability, aggregates $<2 \mathrm{~mm}$ were subjected to wet sieving for $3 \mathrm{~min}$ in the apparatus described by Kemper and Rosenau (1986). Soil particles passing through a $0.25 \mathrm{~mm}$ sieve were dried at $60{ }^{\circ} \mathrm{C}$, weighed and referred to as unstable aggregates. The material remaining on the $0.25 \mathrm{~mm}$ sieve (stable aggregates + coarse grains) was dispersed with 5\% sodium hexametaphosphate. The coarse material was washed with deionised water, dried at $60^{\circ} \mathrm{C}$ and weighed. The initial and final weights of aggregates were corrected for the weight of these coarse particles. The water structural stability index (SSI) was calculated as the weight of 
aggregated soil $(>250 \mu \mathrm{m})$ remaining stable after wet sieving and referred to as a percentage of the total aggregate weight.

\subsection{Field analyses}

Soil water infiltration was measured in the field during the dry season in order to work under comparable extreme dryness conditions with the different soils. The method used was first described by Bouwer (1986) and based on the double-ring infiltrometer. The infiltration rate was monitored by the decrease of the water level within the inner ring. Water in the outer ring was kept at the same level as in the inner one to prevent lateral flow and promote vertical water movement in the soil. The data (3 field replicates) was used to plot the infiltration curves (infiltration rate vs. time). Using exponential regression functions, the data were adjusted to the Kostiakov (1932) equation, $K=c \cdot X^{-}$ a, where $K$ represents the infiltration rate, $X$ the infiltration time, $c$ the initial infiltration rate and a the rate of decline of infiltration. The "parameter c" informs on the extent to which water can be retained into soil immediately after the rain event, whereas "parameter a" informs on the soil hydric saturation (Hemmat et al., 2007). In addition, the "average infiltration rate" (Ir) after 60 minutes was calculated as an index of the infiltration capacity of the soil, not only during the first few minutes but also after an extended rain event.

\subsection{Bulk organic matter characterisation}

Solid-state ${ }^{13} \mathrm{C}$ NMR spectroscopy under quantitative acquisition conditions was employed to assess the main structural components of the SOM in whole soil samples (Wilson, 1990; Preston 1996). In order to circumvent problems derived from paramagnetic minerals, the soil samples were subjected to previous demineralisation treatments (Skjemstad et al., 1994). Approximately $25 \mathrm{~g}$ soil, were shaken with $50 \mathrm{~cm}^{3}$ of $10 \%$ (w:w) hydrofluoric acid for $2 \mathrm{~h}$ in closed polyethylene bottles. After centrifuging for 10 minutes at $3,000 \mathrm{rpm}$, the supernatant was discarded. The demineralisation procedure was repeated up to five times at room temperature. Finally, the remaining residual solid phase was washed 10 times with $40 \mathrm{~cm}^{3}$ deionised water until the $\mathrm{pH}$ was higher than 5 and freeze dried. 
Solid-state ${ }^{13} \mathrm{C}$ NMR spectra were acquired with the cross-polarisation/magic angle spinning (CPMAS) technique performed at $15 \mathrm{kHz}$, using a Bruker Avance III 600 $\mathrm{MHz}$ spectrometer (14.09 T) at a ${ }^{13} \mathrm{C}$ NMR frequency of $150.93 \mathrm{MHz}$. Depending on the sensitivity of the sample, between 2,000 and 25,000 scans per spectrum were accumulated. The pulse repetition rate was set to $0.3 \mathrm{~ms}$, and the contact time was $1 \mathrm{~ms}$ during which a ramped ${ }^{1} \mathrm{H}$ pulse was used to circumvent Hartmann-Hahn mismatches. The chemical shift scale refers to tetramethylsilane $(0 \mathrm{ppm})$ and was adjusted by using glycine (COOH; 176.04 ppm).

For quantifying the contribution of the different $\mathrm{C}$ types to the TOC of the soils, the spectra were divided into various chemical shift regions assigned to carboxyl/carbonyl/amide C (220-160 ppm), aromatic/olefinic C (160-110 ppm), $O$ alkyl C (110-60 ppm), $N$-alkyl/methoxyl C (60-45 ppm) and alkyl C (45-0 ppm) (Knicker et al., 2005). The relative $\mathrm{C}$ distribution was determined by integrating the total signal intensity using the MestReNova Software version 8.1 (Mestrelab Research S.L., Spain) and expressed as a percentage of the TOC. The aromaticity of the SOM was inferred from the signal intensity of the aryl region (160-110 ppm). The ratio between the substituted aryl C (140-160 ppm) and the olefinic and non-substituted aryl C (140-110 ppm) was used as an indicator of the contribution of phenolic carbons in lignin units to the total aryl $\mathrm{C}$. The alkyl-to- $\mathrm{O} / \mathrm{N}$-alkyl $\mathrm{C}$ ratio, which is commonly considered to refer to the degree of decomposition of the organic material and, therefore, as an index of humification (Baldock et al., 1997), was calculated as: alkyl C / (O-alkyl $\mathrm{C}+\mathrm{N}$-alkyl/methoxyl C).

\subsection{Separation and quantification of SOM fractions}

Isolation and quantitative analysis of the different SOM fractions, was carried out by using a protocol similar to that employed by De Blas et al., (2010). Initially, $60 \mathrm{~g}$ soil samples were subjected to lipid removal by Soxhlet extraction with petroleum ether (40-60 ${ }^{\circ} \mathrm{C}$ distilled mixture of hydrocarbons) for $5 \mathrm{~h}$ and the organic phase was dehydrated with anhydrous sodium sulphate, distilled at reduced pressure, and finally desiccated under $\mathrm{N}_{2}$ stream (Almendros et al., 1996). The lipid-free residue of the soil was used for the subsequent extraction of several organic fractions (free particulate organic matter (f-POM); humic acids (HA); fulvic acids (FA); and humin), which were quantitatively determined according to Pansu and Gautheyrou (2006). 
The separation of the particulate, low density fraction with the not-yet decomposed organic particles was carried out by flotation, suspending the soil sample in $2 M$ phosphoric acid (density $1.2 \mathrm{~g} \cdot \mathrm{cm}^{-3}$ ) and mixing it using a blade agitator for $1 \mathrm{~min}$. The floating light soil fraction consisting of f-POM was then isolated by centrifuging the suspension, washed with distilled water and analysed for TOC content.

The resulting soil residue was successively extracted with $0.1 M$ sodium pyrophosphate $(\times 2)$ and $0.1 M$ sodium hydroxide $(\times 4)$. The dark brown supernatant was isolated by centrifugation to finally obtain the total humic extract (HA+FA). Two aliquots were taken from this extract. One of the aliquots $\left(25 \mathrm{~cm}^{3}\right)$ was precipitated with sulphuric acid $(9 M)$ to determine the acid-insoluble fraction (HA) and, by difference with the total humic extract (the other aliquot of $25 \mathrm{~cm}^{3}$ ), the amount of the acid-soluble fraction (FA) (Pansu and Gautheyrou, 2006). The C concentration in these aliquots was determined by wet oxidation in acid medium (Walkley and Black, 1934). The soil residue after the alkaline extraction was washed with distilled water and desiccated at $40{ }^{\circ} \mathrm{C}$. The $\mathrm{C}$ concentration in this residue corresponded to total humin.

For further structural characterisation of the HAs, the total humic extract was acidified at $\mathrm{pH} 2$ with hydrochloric acid and the precipitated HAs were separated of the FAs by centrifugation. The isolated HAs were redissolved in $0.5 \mathrm{M}$ sodium hydroxide and centrifuged at 25,000 rpm (to sediment the clay-sized minerals) precipitated again with $6 M$ hydrochloric acid and dialysed in cellophane bags (Visking ${ }^{\circledR}$ dialysis tubing, MW cut-off 12,000-14,000 Da, pore diameter ca. $25 \AA$ ) until total removal of salts introduced during the extraction (electrical conductivity test). Finally, the HA samples were freeze-dried, homogenised in an agate mortar and stored for analysis.

\subsection{Analyses of the humic acid fraction}

The elemental composition $(\mathrm{C}, \mathrm{H}, \mathrm{N}$ and $\mathrm{S})$ of the HAs was performed by dry combustion $\left(980^{\circ} \mathrm{C}\right)$ on a Carlo Erba CHNS-EA1108 microanalyser and the $\mathrm{C} / \mathrm{N}$ ratio, as well as $\mathrm{O} / \mathrm{C}$ and $\mathrm{H} / \mathrm{C}$ atomic ratios were calculated. It is considered that the $\mathrm{H} / \mathrm{C}$ atomic ratio is associated with the contribution of aliphatic components to the HAs and therefore, inversely related with the aromaticity of the humic samples (Schnitzer and Khan, 1972). 
Concerning visible spectroscopy, the optical density of the purified HAs was measured in a concentration of $0.1 \mathrm{mg} \cdot \mathrm{cm}^{-3}$ in $0.02 M$ sodium hydroxide. The absorbance at 465 $\mathrm{nm}\left(\mathrm{E}_{4}\right)$ was used as a surrogate of the aromaticity and diagenetic maturity of the SOM (Traina et al. 1990), whereas the ratio of the absorbance at $465 \mathrm{~nm}$ to that at $665 \mathrm{~nm}$ $\left(\mathrm{E}_{4} / \mathrm{E}_{6}\right.$ ratio) was used as an indicator of the average molecular size of HAs (Chen et al., 1977).

The IR spectra of the samples were obtained on a Bruker IFS 55 mid-infrared Fourier transform spectrophotometer equipped with a diamond Golden Gate attenuated total reflectance adaptor (FT-IR/ATR). For resolution enhancement, the digital spectra were processed by an algorithm consisting of subtracting the raw spectrum from a positive multiple of its second derivative (Almendros and Sanz, 1992). Resolution-enhanced spectra showed defined sharp peaks, which were assigned following literature on HAs and lignins (MacCarthy and Rice, 1985) i.e., aliphatic structures (2920 and $1460 \mathrm{~cm}^{-1}$ ), carboxyl groups $\left(1720 \mathrm{~cm}^{-1}\right), \mathrm{N}$-containing groups $\left(1640\right.$ and $\left.1540 \mathrm{~cm}^{-1}\right)$, aromatic structures $\left(1620\right.$ and $\left.1510 \mathrm{~cm}^{-1}\right)$, etc. In addition, the resolution enhanced spectra from several samples showed a clear pattern (viz., peaks at 1510, 1460, 1320, 1260, 1410 and $1030 \mathrm{~cm}^{-1}$ ) coinciding with that of plant lignins (Fengel and Wegener, 1984). The use of the second derivative spectra allowed the semi-quantitative measurement of peak intensities (as valleys), precluding problems of baseline tracing (Fernández-Getino et al., 2013). The intensities of the major peaks were expressed as total abundances (sum= $100)$.

\subsection{Statistical analyses}

Data treatments were carried out using the Statistica software v.7.0 (StatSoft, 2005). As a first step, exploratory data treatments based on discriminant analysis were applied to identify the main factors determining the variability of the soils as regards their hydrophysical quality. Discriminant analysis allows extracting the independent variables most relevant to discriminate among predefined groups. The groups considered for this study were topography, climate, vegetation, parent rock, soil use and humus type. After automatic forward variable selection, discriminant analysis yielded coefficients of the individual variables in the discriminant functions, indicating the extent to which the samples are correctly classified into the originally defined groups. 
Simple regression models were then employed to establish SOM descriptorsquantitative data for the different humic fractions in addition to chemical and spectroscopic data determined for the whole SOM and the isolated HAs - which could be used to describe typical physical properties related to soil quality.

Canonical correlation analyses were also applied. The strength of this technique is its ability to identify the strongest associations existing between two set of variables simultaneously, rather than calculating simple pairwise correlations (Gittins, 1985). The models examined were built up from two data matrices yielding two canonical variates: one consisting of a linear combination of SOM properties (variate 1 on the $x$-axis) and other consisting of linear combination of soil physical characteristics (variate 2 on the $y$ axis). For reliable results with this technique, similar numbers of variables are needed in each group and these numbers must be lower than the total number of samples examined. Therefore, independent models were examined using selected SOM characteristics grouped into two progressive information levels, a) ${ }^{13} \mathrm{C}$ NMR from the whole SOM and b) spectroscopic features of the HA fraction. In the same way, the soil physical properties were also divided into a) general physical parameters (i.e., soil porosity, AWC and FAC) and b) soil hydrophysical descriptors (i.e., Kostiakov's equation coefficients).

Other non-supervised statistical models such as multidimensional scaling (MDS) (Kruskal, 1964) using the 1-Pearson correlation index as affinity index, were also employed. These models help to define clusters of variables including soil physical characteristics and SOM descriptors, which can be displayed as groups in a twodimensional space according to their mutual correlations.

\section{RESULTS AND DISCUSSION}

\subsection{Physical and chemical properties of the soils}

The study region is characterised by coarse to medium-textured soils (sandy-clay-loam, sandy-loam, loam and clay-loam) except for the Vertisol (C2) and one of the Histosols 
(H3), which display comparatively fine textures (silty-clay and silty-clay-loam, respectively) (FAO, 2006). The soils developed in mountain and hillside areas exhibit slightly acid $\mathrm{pH}$ values associated to low base saturation of the soil exchange complex (Table 2). On the contrary, soils on sedimentary environments show neutral to moderately basic $\mathrm{pH}$ values. These soils are base-saturated with $\mathrm{Ca}^{2+}$ and $\mathrm{Mg}^{2+}$ as the dominant cations in the exchange complex, as a result of the carbonated nature of the geological substrate in most of them. The total $\mathrm{CaCO}_{3}$ concentrations range between 6.8 and $8.8 \mathrm{~g} \cdot 100 \mathrm{~g}^{-1}$ (Table 2). The CEC of the surface horizons varies widely depending on soil type and, more specifically, on SOM content and soil texture. The highest values was found in Histosols $\mathrm{H} 1-\mathrm{H} 3\left(>58 \mathrm{cmol}_{\mathrm{c}} \cdot \mathrm{kg}^{-1}\right)$, in Vertisol C2 $\left(\right.$ ca. $\left.63 \mathrm{cmol}_{\mathrm{c}} \cdot \mathrm{kg}^{-1}\right)$ and in Kastanozem A1 ( ca. $45 \mathrm{cmol}_{\mathrm{c}} \cdot \mathrm{kg}^{-1}$ ). This coincides, in the former case, with high TOC and, in the latter, with the high percentage of clay-sized particles. The other soil groups show CEC values close to $20 \mathrm{cmol}_{\mathrm{c}} \cdot \mathrm{kg}^{-1}$ (Table 2).

The TOC concentrations in surface mineral soils range between $0.67 \mathrm{~g} \cdot 100 \mathrm{~g}^{-1}$ in sample $\mathrm{C} 1$, a culture, to $7.38 \mathrm{~g} \cdot 100 \mathrm{~g}^{-1}$ in sample $\mathrm{F} 1$, a forest. Agricultural and abandoned soils show the lowest average TOC levels $(0.80 \pm 0.13$ and $2.19 \pm 0.47 \mathrm{~g} \cdot 100$ $\mathrm{g}^{-1}$, respectively) whereas in forest ecosystems there is no clear pattern $(4.01 \pm 2.1 \mathrm{~g} \cdot 100$ $\mathrm{g}^{-1}$ TOC). Moreover, the highest accumulation of TOC occurs in the Histosols (H1-H3) where waterlogging conditions favour slow mineralisation rates leading to mean TOC values of $22.19 \pm 1.43 \mathrm{~g} \cdot 100 \mathrm{~g}^{-1}$ (Table 2 ). The $\mathrm{C} / \mathrm{N}$ ratio ranges between 10 and 18 , hight $\mathrm{C} / \mathrm{N}$ ratios being observed in Histosols and soils developed under forest vegetation (between 13 and 17) whereas in cultivated and abandoned soils the $\mathrm{C} / \mathrm{N}$ ratios were comparatively lower (between 10 and 14).

Physical properties are reported in Table 3. The most elevated bulk densities are associated with cultivated $\left(1.60 \pm 0.14 \mathrm{~g} \cdot \mathrm{cm}^{-3}\right)$ and abandoned soils $\left(1.37 \pm 0.04 \mathrm{~g} \cdot \mathrm{m}^{-3}\right)$ which, in fact, are above the optimal range of $0.9-1.2 \mathrm{~g} \cdot \mathrm{cm}^{-3}$ (Reynolds et al., 2009) indicating possible soil compaction. These values are significantly greater than those for the forest soils that, excluding sample R2, show a mean bulk density of $1.03 \pm 0.11$ $\mathrm{g} \cdot \mathrm{cm}^{-3}$. The lowest values occur in the organic soils $\left(0.67 \pm 0.13 \mathrm{~g} \cdot \mathrm{cm}^{-3}\right)$. Correspondingly, the soils under agricultural and abandoned uses are deficient in the total amount of pore space in the surface horizons, whereas Histosols and forest soils show a total porosity above $50 \%$, with the only exception of sample R2 (Table 3 ), in which the comparatively low porosity (39\%) might be related to the management of this 
forest area which is, in fact, given over to recreational use. Human trampling and biking activities in the area could adversely affect soil porosity with the concomitant increase of bulk density and compaction of soil surface (Lei, 2004).

The water stable aggregation of the studied soils is in the medium/high range, showing SSI $>70 \%$ in most cases (Table 3 ), which indicates a highly stable structure. The lower SSI values coincide with samples $\mathrm{H} 2, \mathrm{C} 2$ and $\mathrm{C} 3(67.4 \%, 60.6 \%$ and $33.5 \%$, respectively). In cultivated soils, relatively low values of SSI could be associated with aggregate breakdown during tillage. In the case of H2 (Fibric Histosol), the high amount of recognisable plant tissues can determine the lack of strong organo-mineral interactions and lead to unstable structure.

Regarding the water retention capacity of the soils, large differences were obtained for stored water at FC $(-0.03 \mathrm{MPa})$ and PWP $(-1.5 \mathrm{MPa})$, ranging from 7.3 to $82.5 \mathrm{~g} \cdot 100$ $\mathrm{g}^{-1}$, at FC, and from 2.0 to $69.3 \mathrm{~g} \cdot 100 \mathrm{~g}^{-1}$, at PWP. However, values of AWC are generally small $\left(<10 \mathrm{~g} \cdot 100 \mathrm{~g}^{-1}\right)$, with the exception of Histosols $\left(15.1 \pm 1.8 \mathrm{~g} \cdot 100 \mathrm{~g}^{-1}\right)$, cultivated soil C2 $\left(12.1 \mathrm{~g} \cdot 100 \mathrm{~g}^{-1}\right)$ and forest soil $\mathrm{F} 1\left(13.8 \mathrm{~g} \cdot 100 \mathrm{~g}^{-1}\right)$. In addition, some soils, including Histosols, cultivated and abandoned soils, exhibit low values of FAC, even under the limit of $34 \%$ established as the value of optimal balance of water storage and air provision for soil biological activity (Reynolds et al., 2002).

Table 3 also shows the infiltration parameters calculated by adjusting the field data to the Kostiakov's (1932) equation. In the case of Histosols (P1-P3) the results were poorly reproducible due to the limitations of the double-ring infiltrometer method, which requires data acquisition under soil dryness conditions. The "parameter c" defined as the initial infiltration rate, informs on the extent to which water can be retained into soil immediately after the rain event. In the studied soils, this parameter varies between 2.8 and $29.9 \mathrm{~mm} \cdot \mathrm{min}^{-1}$, suggesting a very different behaviour of the soils in the early infiltration stages. In fact, it is possible to distinguish between soils with low (F1, F3 and R2), medium (A1, A3, C1, C2, C3 and F2) and high (R1 and A2) initial infiltration rates. On the other hand, "parameter a" indicates the ease with which soils are water-saturated during the infiltration process. This parameter ranged from 0.16 to 0.58 , with a mean value of $0.38 \pm 0.14$. From these two parameters, it was possible to distinguish between soils highly vulnerable to water erosion and soils with good response to rainfall events and, therefore, low vulnerability to degradation processes. The greater the value of $c$, the greater the initial infiltration capacity, whereas 
the lower the value of $a$, the lower the rate of decline of infiltration. The lowest water infiltration capacity was found in soil F1, showing limited volume of water infiltrated during the field experiment and rapid soil saturation (parameter $c=2.8 \mathrm{~mm} \cdot \mathrm{min}^{-1}$; parameter $a=0.55)$. The opposite situation corresponds to soil $\mathrm{R} 1$, which infiltrated a large volume of water and shows a comparatively low rate of infiltration decline (parameter $c=20.4 \mathrm{~mm} \cdot \mathrm{min}^{-1}$; parameter $\mathbf{a}=0.27$ ) (Table 3$)$.

\subsection{Solid-state ${ }^{13}$ C NMR spectroscopy of SOM}

The CPMAS ${ }^{13} \mathrm{C}$ NMR spectra of HF-treated soil samples are shown in Figure 2, and the content of the major C-types, expressed as a percentage of the total spectral area, are given in Table 4.

The carbonyl region $(220-160 \mathrm{ppm})$ is dominated by a peak at $173 \mathrm{ppm}$, and shows similar intensities in all studied samples (Figure 2). This signal is traditionally attributed to $\mathrm{C}$ in carboxyl groups and amide linkages in peptides. The chemical shift region for aryl carbons (160-110 ppm) shows a main peak at $130 \mathrm{ppm}$ derived mainly from unsubstituted aromatic $\mathrm{C}$ but also from olefinic C. Signals of syringyl and guaiacyl units (Wilson, 1987) are also evident in some samples (shoulder between 160 and 140 ppm). The $O$-alkyl C chemical shift region $(110-60)$ is the main contributor to the ${ }^{13} \mathrm{C} \mathrm{NMR}$ spectra (Table 4) with peaks at $83 \mathrm{ppm}, 73 \mathrm{ppm}$ and $63 \mathrm{ppm}$ assigned to $\mathrm{C}_{2}$ to $\mathrm{C}_{5}$ in carbohydrates and a peak between 110 and $90 \mathrm{ppm}$ commonly attributed to the anomeric $\mathrm{C}_{1}$ in carbohydrates or tannin-like structures. In the chemical shift region between 60-45 ppm, it has been identified a small peak at $56 \mathrm{ppm}$ (Figure 2) for methoxyl $\mathrm{C}$ in lignin which can also contain contribution of $\mathrm{N}$-alkyl C (Almendros et al., 1992; Knicker, 2000). The chemical shift region for alkyl C (45-0 ppm) shows the typical maximum at ca. $30 \mathrm{ppm}$ for methylene carbons (lipids, plant waxes, cutans, suberans, peptides, etc). A small peak or shoulder around $20-25 \mathrm{ppm}$ is frequently attributed to $\mathrm{C}$ in short-chain branched structures or terminal methyl groups (KögelKnabner, 2002).

In general, the alkyl C content (0-45 ppm) ranges from 24.7 to $36.5 \%$, and that of $O$ alkyl C (45-110 ppm) from 31.0 to $47.0 \%$, amounting to more than a half of the TOC in these soils. The calculated alkyl-to- $O / N$-alkyl $\mathrm{C}$ ratio indicates dominance of $\mathrm{O} / \mathrm{N}$-alkyl carbons over non-substituted aliphatic structures. This ratio exhibits similar values in all 
studied samples (Table 4), pointing to comparable degree of SOM, although it must be considered that the kind of litter inputs and the interactions between SOM and the mineral phase may affect this ratio. The main differences are recognised in the contribution of the aryl $\mathrm{C}$ to the total $\mathrm{C}$ intensity (5.3-25.8\%), where cultivated soils (C1 and C3) show the highest aromaticity (Table 4). The opposite trend is found in Histosols (H1-H3), with low proportions of aromatic C. In the case of spectra of forest soils (F1-F3) and Histosols (H1-H3) (Figure 2c and 2e), the signal at $130 \mathrm{ppm}$ is accompanied by a small signal at $154 \mathrm{ppm}$, not evident in the spectra of the other samples, suggesting lignin as a major contributor to the aryl C-region. This is also reflected in the ratio between the substituted aryl C (140-160 ppm) and the olefinic and non-substituted aryl C (140-110 ppm), referred to as lignin contribution (Table 4), which shows comparatively high values mainly in the case of forest soils (F1-F3).

\subsection{SOM fractions}

Table 5 shows the distribution of total SOM into the different organic fractions isolated from the soils (free lipids, f-POM, FA, HA and humin) referred to (1) the total soil weight and (2) the TOC.

In general, the humin fraction amount to more than half of the TOC. Humin concentration is only comparatively low in samples R1 (46.5\%), R2 (42.4\%) and H3 (38.1\%). The content of the colloidal fractions (HA and FA) represents a significant proportion of the TOC, ranging from $32.6 \%$ in $\mathrm{F} 3$, a forest soil, to $53.4 \%$ in $\mathrm{H} 3$, a Histosol.

The f-POM only represents between 0.2 and $8.7 \%$ of the TOC; the cultivated soils showing the lowest proportion of this SOM fraction, which could be related with the removing of crop residues during the harvest and/or a tillage-induced increase of the Cturnover rates. Concerning the concentration of free lipids, this fraction represents less than $1 \%$ of TOC, even in soils under wetland vegetation $(\mathrm{H} 1-\mathrm{H} 3)$ which is commonly associated to high amounts of lipids (Stevenson, 1994; Almendros et al., 1996).

\subsection{Characterisation of soil HAs}

Table 6 shows the results of the elementary analysis of HAs, as well as its $\mathrm{C} / \mathrm{N}$ ratio and $\mathrm{H} / \mathrm{C}$ and $\mathrm{O} / \mathrm{C}$ atomic ratios. The $\mathrm{C}$ content ranges from 52.7 to $57.7 \mathrm{~g} \cdot 100 \mathrm{~g}^{-1}$, the 
highest value corresponding to a Histosol (H2) and the lowest to a cultivated soil (C2). The $\mathrm{H} / \mathrm{C}$ atomic ratio, inversely related to aromaticity, provides information about the degree of diagenetic transformation of SOM (Schnitzer and Khan, 1972). In the case of agricultural soils the low $\mathrm{H} / \mathrm{C}$ ratios suggest intense maturation of the HAs, whereas soils with relatively high $\mathrm{H} / \mathrm{C}$ ratios are related to HAs with marked aliphatic character. This is the case of most forest soils and Histosols (Table 6).

Concerning visible spectroscopy, $\mathrm{E}_{4}$ optical density is considered to increase with the condensation and aromaticity of the HAs, whereas the $\mathrm{E}_{4} / \mathrm{E}_{6}$ ratio decreases with HA molecular weight and has been frequently used as an index of the degree of association between humic molecules (Chen et al., 1977). The $\mathrm{E}_{4}$ values of the studied HAs range from 0.61 to $1.38 \mathrm{AU}$ (Table 7). Cultivated soils show higher $\mathrm{E}_{4}$ values than the other groups with an average of $1.73 \pm 0.33 \mathrm{AU}$, whereas Histosols, forest and abandoned soils display average $\mathrm{E}_{4}$ values of $0.85 \pm 0.23 ; 0.72 \pm 0.33$ and; $0.77 \pm 0.33$ AU respectively. This coincides with the results of elementary analysis of HAs (Table 6) showing the aromatic character of the HAs from cultivated soils and interpreted as the preferential biodegradation of aliphatic domains favoured by the enhanced effectiveness of the biogeochemical C-cycle in soils subjected to periodic tillage (Schnitzer et al., 2006; Tinoco et al., 2010). As regards the $\mathrm{E}_{4} / \mathrm{E}_{6}$ ratio, there are comparatively large values in forest soils and Histosols, with the highest value in sample F2 (6.38). Conversely, the $\mathrm{E}_{4} / \mathrm{E}_{6}$ values are comparatively low in cultivated soils and abandoned lands, with the lowest value (4.04) in sample C2.

Table 7 shows the standardised intensities of the major peaks of the IR spectra calculated from the second-derivative IR data. This Table also displays ratios between the intensities of peaks at 1510 and $2920 \mathrm{~cm}^{-1}$ and between peaks at 1720 and 1510 $\mathrm{cm}^{-1}$, respectively used, as indicators of the presence of aromatic and carboxyl groups in the structure of HAs. Cultivated soils, mainly $\mathrm{C} 1$ and $\mathrm{C} 2$, show comparatively high $1510 / 2920 \mathrm{~cm}^{-1}$ ratios, as well as low $1720 / 1510 \mathrm{~cm}^{-1}$ ratios, pointing to intense macromolecular complexity of this HAs. These findings agree with values of $E_{4}$ optical density, highlighting the important effect of cultivation and tillage practices on the progress of SOM humification. On the contrary, forest soils (F1-F3 and R1-R2) exhibit low aromaticity and high oxidation (HAs with conspicuous lignin band in the IR spectra), interpreted as HAs at early humification stages. 


\subsection{Discriminant analysis}

The results of the discriminant analysis are presented in Figure 3, showing the automatic classification of the samples in the space defined by the two first discriminant functions obtained by using humus type, topography, climate, vegetation, parent rock or soil use, as classification factors.

This treatment failed in showing sharp sample clusters with any of these classification factors, except humus type (Figure 3a), which exhibits $100 \%$ cases correctly classified and high significant $(P<0.01)$ degree for the two first discriminant functions. The topography and climate also lead to models valid to classify up to $92.9 \%$ of the samples correctly (Figure $3 \mathrm{~b}$ and $3 \mathrm{c}$ ) although their discriminant functions are less significant $(P<0.05)$ or even not significant $(P>0.05)$. On the other hand (Figures $3 \mathrm{~d}, 3 \mathrm{e}$ and $3 \mathrm{f})$ the physical variables studied weakly reflect the influence of vegetation, parent rock and soil use $(85.7 \%$ and $78.6 \%$ of cases correctly classified, respectively), particularly in the latter case, where no significant $(P>0.05)$ discriminant functions were obtained.

These results suggest that the soil samples studied define a soil quality gradient to a large extent controlled by humus features, indicating that SOM characteristicscompared to other biotic, abiotic and anthropogenic factors-is a relevant factor with regard to soil hydrophysical properties. Consequently, the following strategies are focused on exploring chemical descriptors of SOM as indicators of the physical status of the soils.

\subsection{Correlation studies}

Table 8 shows significant $(P<0.05)$ linear regression coefficients between soil physical variables and variables informing on the characteristics of the SOM. The SSI, which is a physical indicator of soil resistance to aggregate breakdown, is not shown in this Table due to it was not significantly correlated with any SOM fraction or structural component. As mentioned above, most of the fourteen soils were homogeneous and highly stable at the macroaggregate level. This low variability and the weak correlations between SSI and the SOM composition could be related to the importance of mineral phases in these soils which, rather than organic materials, could be acting as dominant stabilizing agents. This coincides with the results by other authors in Mediterranean soils (Boix- 
Fayos et al., 2001; Virto et al., 2011) and other temperate environments (Six et al., 2000), suggesting structural stability favoured by the influence of silicate clays and calcium carbonates.

When considering the correlation indices between the physical variables and the chemical composition of the SOM, it is possible to distinguish SOM attributes correlated with physical properties involved in water storage functions (i.e., FC, PWP and AWC) and soil porosity (Table 8). The distribution of the SOM among the different organic pools is correlated with some physical variables. This is the case with f-POM, which shows significant correlations $(P<0.05)$ with the FAC, suggesting a role of slightly-decomposed plant residues in the provision of air in the soil; and with parameter $a$, indicating that soils with high amounts of f-POM are associated with elevated rates of decline of water infiltration capacity.

On the contrary, parameter $c$ and the calculated $I r$, which are hydrophysical indicators of the infiltration capacity of soil during the first few minutes and after an extended rain event respectively, are highly correlated with the concentration of the soil FA fraction (Table 8). The FAs also shows significant correlations with the water storage parameters FC, PWP and AWC, although the variables are, in this case, inversely related, indicating that soils with an important contribution of FA to the total SOM may also display some problems of water storage despite its appropriate response to water infiltration processes. The concentration of the remainder SOM fractions (free lipids, HAs and humin) did not show significant correlations with the soil physical attributes, and are not displayed in Table 8.

In relation to correlations obtained between ${ }^{13} \mathrm{C}$ NMR spectroscopic data from whole soil samples and physical parameters, soil porosity is directly correlated with the concentrations of $O$-alkyl $\mathrm{C}$ and alkyl $\mathrm{C}$, and inversely correlated with carbonyl $\mathrm{C}$ and aryl $\mathrm{C}$. These facts, together with the above correlation between the soil porosity and the soil $\mathrm{C} / \mathrm{N}$ ratio (Table 8 ) point to the importance of SOM with structural similarity with precursor plant biomacromolecules in the adequate maintenance of soil pore space. The same trend is also observed with physical variables informing on water storage and, more specifically with the AWC, which reflects the actual amount of water available to 
soil organisms. On the other hand, parameter a shows inverse correlation with carbonyl $\mathrm{C}$ and aryl C (Table 8), but is positively correlated with $O$-alkyl C which,- - together with the above correlations between this parameter and the f-POM fraction-suggests that accumulation of plant-derived $O$-alkyl structures result into high water saturation rates.

Apart from the correlations between soil physical attributes and bulk SOM characteristics, the linear correlations between physical variables and molecular features of the HA fractions isolated from the corresponding soils are shown in Table 9. The results suggest that additional variability of some physical properties in the studied soils can be explained in terms of spectroscopic features of HAs. This is the case with e.g., soil porosity and parameter $a$, in such a way that HAs with marked aliphatic character (inferred from the $1460 \mathrm{~cm}^{-1}$ alkyl IR band) and relatively low degree of humification (reflected in the $\mathrm{E}_{4}$ optical density and the intensity of the IR band at $1510 \mathrm{~cm}^{-1}$ ) are associated with high total porosity and rapid decline of water infiltration capacity. It is important that -at this specific organisational level of the SOM-the results are consistent with those obtained from the ${ }^{13} \mathrm{C}$ NMR information (Table 8), which adds to the idea that HAs represent a biogeochemical record of soil forming processes and, to large extent, may be responsible for the structure and activity of the soil system as a whole (Almendros, 2008).

\subsection{Multivariate analyses}

Regarding canonical regression analyses, Figure 4 shows the correlation between the canonical variates (canonical correlation coefficients) and the strength (and sign) of the contribution of the original variables (shown as bar diagrams). When considering soil physical parameters, significant correlation $(P<0.05)$ was found for SOM descriptors in both models corresponding to successive organisational levels of the SOM. In the model from the ${ }^{13} \mathrm{C}$ NMR information (Figure 4a), variate 1 displays a positive coefficient for the lignin contribution - calculated as the ratio between the substituted aryl C (140-160 ppm) and the olefinic and non-substituted aryl C (140-110 ppm)-and negative coefficients for carbonyl and aryl C. At the next information level defined by the spectroscopic characteristics of the HAs (Figure 4b), variate 1 shows a negative 
coefficient for $\mathrm{E}_{4}$ optical density, a surrogate of aromaticity, but positive coefficients for the $1460 \mathrm{~cm}^{-1}$ IR peak-associated to aliphatic structures - and $1720 \mathrm{~cm}^{-1}$ IR peakcharacteristic for carboxyl groups in HAs. These results are in the line with those from the previous simple correlations; SOM of low degree of aromaticity and formed from comparatively high contribution of plant-derived macromolecules is related to high values of porosity, AWC and FAC.

Canonical regression analyses also revealed strong associations between hydrophysical properties and SOM characteristics. For the first SOM organisational level (Figure 4c) a weakly significant canonical correlation $(P<0.10)$ was obtained between the ${ }^{13} \mathrm{C} N \mathrm{NR}$ quantitative information and the soil infiltration parameters. The spectroscopic features defining variate 1 display negative coefficients for the $\mathrm{O}$-alkyl $\mathrm{C}$ and the $\mathrm{N}$ alkyl/methoxyl C. As variate 2 has a positive coefficient for parameter $c$ but a negative coefficient for parameter $a$, the results could be interpreted as the dominance of SOM with important contribution of substituted aliphatic structures in soils with low initial infiltration rates (low values of parameter c) and low resistance to water saturation (high values of parameter a). The same pattern was observed when considering canonical correlations between spectroscopic features of HAs and infiltration parameters (Figure $4 d)$. Variate 1 displays negative coefficients for $E_{4} / E_{6}$ ratio and for the intensity of the $1460 \mathrm{~cm}^{-1}$ IR peak, whereas the IR band at $1720 \mathrm{~cm}^{-1}$ shows a positive coefficient (Figure 4d). As regards canonical variate 2, it shows a positive coefficient for parameter $c$ and a negative coefficient for parameter a. Once again, the two parameters from the Kostiakov equation suggest that SOM of weak aromaticity and low humification degree coincides with suboptimum soil response to rainfall events and potential problems of water erosion, i.e. low infiltration capacity and high water saturation rates immediately after the rain events (Masri and Ryan, 2006).

Further unsupervised classification of the variables was achieved by MDS in which all variables were plotted as points in a plane after dimensional reduction by applying an iterative gradient algorithm. In this plot the distances between points (variables in this case) are optimised to represent the extent of their mutual correlations (Figure 5). Such a plot primarily illustrates the collinearity existing between variables, but could also be used to infer possible cause-to-effect relationships between SOM and physical variables. 
Figure 5 illustrates two well-defined groups of physical properties in our soils: group A, composed by a series of soil physical attributes associated with SOM features typical for early stages of humification or stabilization; and group $\mathrm{B}$, consisting of physical descriptors related to SOM at advanced diagenetic transformation stages.

The first group of variables (Figure 5) comprises most physical variables including airand water storage parameters (i.e., FAC, FC, PWP and AWC), soil porosity, parameter $a$ and SSI, which were not correlated with any SOM feature. In agreement with the previous results of correlation models and canonical regression analyses, these attributes are associated with SOM properties indicating comparatively raw humus, marked aliphatic character - inferred from the intensities of the 2920 and $1460 \mathrm{~cm}^{-1}$ alkyl bands and the strong contribution of the alkyl and $O$-alkyl $\mathrm{C}$ to the total ${ }^{13} \mathrm{C}$ NMR signal of the SOM - and preservation of the lignin signature - reflected in the intensity of the 1270 $\mathrm{cm}^{-1}$ IR peak. In this way, a series of properties typical for SOM of comparatively low humification stages is associated with soil properties involved in the maintenance of the main physical functions (physical support, air provision and water storage). The fact that the SSI appears included in this first group could be related to the moderate aliphaticity, with a positive effect on the formation and maintenance of soil organomineral complexes leading to the stabilisation of soil macrostructure by hydrophobic forces (Piccolo and Mbagwu, 1999). This is in agreement with the results reported by other authors (Tisdall and Oades, 1982; Elliot, 1986), describing that cohesion between particles in macroaggregates is strongly associated with slightly decomposed organic debris acting as binding agents.

Parameter $\mathbf{a}$ is related to SOM with aliphatic character. As this parameter indicates the ease of soils to water saturation during the infiltration process, this reinforces the idea that SOM of weak humification degree coincides with unfavourable response of Mediterranean soils to rainfall events. To some extent, this effect could also be causally associated with moderate water repellency in soils containing SOM with substantial amounts of alkyl hydrophobic constituents (Doerr et al., 2000).

On the other hand, group B includes physical variables $I r$, parameter $c$ and soil bulk density, in addition to $\mathrm{HA}$ variables such as the contribution of aryl $\mathrm{C}$ to the total ${ }^{13} \mathrm{C}$ NMR signal of the SOM, the $\mathrm{E}_{4}$ optical density and the intensities of the IR bands at 
1510 and $1540 \mathrm{~cm}^{-1}$. High values of Ir and parameter $c$ were associated with high humification degree and appropriate water infiltration capacity.

\section{CONCLUSIONS}

The progressive stability of the SOM (defined by surrogates such as aromaticity, condensation degree, lignin signature displayed in the IR spectra and $O$-alkyl C contribution to the total ${ }^{13} \mathrm{C}$ NMR signal) was found correlated with soil physical variables. For instance, in our samples, SOM with predominantly aliphatic character and comparatively low maturity tend to be associated with the successful maintenance of soil pore space but, at the same time, with suboptimum infiltration properties.

These results could have implications on soil management practices in Mediterranean ecosystems aiming to enhance its physical functions. The characterisation of soil physical status on the basis of SOM qualitative descriptors, could be useful in forecasting soil degradation processes, even when no cause-to-effect relationships are assumed. Moreover, in already degraded soils, the knowledge of the sources of variability for each physical property may provide valuable information for ecosystems restoration by adapting SOM inputs with specific characteristics to particular soil degradation problems (i.e. soil compaction, waterlogging, water erosion, etc.).

\section{ACKNOWLEDGEMENTS}

This research has been granted by project CGL2008-04296 of the Spanish DGCyT. L. Recio-Vazquez would like to thank the Spanish Ministry of Economy and Competitiveness (former Ministry of Science and Innovation) for the financial support (FPI Predoctoral Research Grant). The Centre for Research, Innovation and Technology (CITIUS) of the University of Seville is acknowledged for providing access to their NMR facilities.

\section{REFERENCES}

AEMET (Agencia Estatal de Meteorología), 2013. Available at: http://www.aemet.es/es/serviciosclimaticos/datosclimatologicos/valoresclim atologicos. 
Almendros, G., 2008. Humic substances, in: Chesworth, W. (Ed.), Kluwer Encyclopedia of Soil Science. Springer, Dordretch, pp. 97-99.

Almendros, G., Martínez, A.T., González, A.E., González-Vila, F.J., Fründ, R., Lüdemann, H.-D., 1992. CPMAS C-13 NMR-study of lignin preparations from wheat straw transformed by 5 lignocellulose-degrading fungi. J. Agric. Food Chem. 40, 1297-1302.

Almendros, G., Sanz, J., 1992. A structural study of alkyl polymers in soil after perborate degradation of humin. Geoderma 53, 79-95.

Almendros, G., Sanz, J., Velasco, F., 1996. Signatures of lipid assemblages in soils under continental Mediterranean forests. Eur. J. Soil Sci. 47, 183-196.

Arshad, M.A., Coen, G.M., 1992. Characterization of soil quality: physical and chemical criteria. Am. J. Alternative Agric. 7, 25-31.

Baldock, J.A., Oades, J.M., Nelson, P.N., Skene, T.M., Golchin, A., Clarke, P., 1997. Assessing the extent of decomposition of natural organic materials using solid-state ${ }^{13}$ C NMR spectroscopy. Aust. J. Soil Res. 35, 1061-1083.

Blake, G.R., Hartge, K.H., 1986. Particle density, in: Klute, A. (Ed.), Methods of Soil Analysis. Part 1; 2nd ed. American Society of Agronomy and Soil Science Society of America, Madison, pp. 363-375.

Boix-Fayos, C., Calvo-Cases, A., Imeson, A.C., Soriano-Soto, M.D., 2001. Influence of soil properties on the aggregation of some Mediterranean soils and the use of aggregate size and stability as land degradation indicators. Catena 44, $47-67$.

Bouwer, H., 1986. Intake rate: cylinder infiltrometer, in: Klute, A. (Ed.), Methods of Soil Analysis. Part 1; 2nd ed. American Society of Agronomy and Soil Science Society of America, Madison, pp. 825-844.

Bouyoucos, G.J., 1927. The hydrometer as a new method for the mechanical analysis of soils. Soil Sci. 23, 343-354.

Bower, C.A., Wilcox, L.V., 1965. Chemical and Microbiological Properties. in: Klute, A. (Ed.), Methods of Soil Analysis. Part 2. American Society of Agronomy and Soil Science Society of America, Madison, pp. 933-951. 
Chapman, H.D., Pratt, P.F., 1961. Methods of Analysis for Soil, Plants and Water. University of California, Division of Agricultural Science, Berkeley, Riverside.

Chen, Y., Senesi, N., Schnitzer, M., 1977. Information provided on humic substances by $\mathrm{E}_{4} / \mathrm{E}_{6}$ ratios. Soil Sci. Soc. Am. J. 4, 352-358.

De Blas, E., Rodríguez-Alleres, M., Almendros, G., 2010. Speciation of lipid and humic fractions in soils under pine and eucalyptus forest in northwest Spain and its effect on water repellency. Geoderma 155, 242-248.

Doerr, S.H., Shakesby, R.A., Walsh, R.P.D., 2000. Soil water repellency: its causes, characteristics and hydro-geomorphological significance. Earth Sci. Rev. 51, $33-65$.

Doran, J.W., Parkin, T.B., 1994. Defining and assessing soil quality, in: Doran J.W., Coleman D.C., Bezdick D.F., Stewart B.A. (Eds.), Defining Soil Quality for a Sustainable Environment. Soil Sci. Soc. Am. J., Special Publication 35, pp. $3-21$.

Doran, J.W., Sarrantonio, M., Lieberg, M.A., 1996. Soil health and sustainability. Adv. Agron. 56, 1-54.

Drouineau, G., 1942. Dosage rapide du calcaire actif du sol: Nouvelles données sur la séparation et la nature des fractions calcaires. Ann. Agron. 12, 441-450.

Duchaufour, P., Jacquin F., 1975. Comparaison des processus d'humification dans les principaux types d'humus forestiers. Bull. Assoc. Fr. Étud. Sol 1, 29-36.

Elliott, E.T., 1986. Aggregate structure and carbon, nitrogen and phosphorus in native and cultivated soils. Soil Sci. Soc. Am. J. 50, 627-633.

FAO, 2006. Guidelines for soil description, 4th ed. Food and Agriculture Organization of the United Nations FAO, Rome.

Fengel, D., Wegener, G., 1984. Wood: Chemistry, Ultrastructure, Reactions. De Gruyter, Berlin.

Fernández-Getino, A.P., Hernández, Z., Piedra-Buena, A., Almendros, G., 2013. Exploratory analysis of the structural variability of forest soil humic acids 
based on multivariate processing of infrared spectral data. Eur. J. Soil Sci. 64, 66-79.

Gittins, R., 1985. Canonical Analysis: A Review with Applications in Ecology. Springer, Berlin.

Gregorich, E.G., Carter, M.R., Angers, D.A., Monreal, C.M., Ellert, B.H., 1994. Towards a minimum data set to assess soil organic matter quality in agricultural soils. Can. J. Soil Sci. 74, 367-385.

Guitián, F., Carballas, T., 1976. Técnicas de Análisis de Suelos. Pico Sacro, Santiago de Compostela.

Haynes, R.J., 2005. Labile organic matter fractions as central components of the quality of agricultural soils: an overview. Adv. Agron. 85, 221-268.

Hemmat, A., Ahmadi, I., Masoumi, A., 2007. Water infiltration and clod size distribution as influenced by ploughshare type, soil water content and ploughing depth. Biosyst. Eng. 97, 257-266.

Hendershot, W.H., Duquette, M.A., 1986. Simple barium-chloride method for determining cation-exchange capacity and exchangeable cations. Soil Sci. Soc. Am. J. 50, 605-608.

IUSS Working Group WRB, 2007. World Reference Base for Soil Resources 2006, first update 2007. World Soil Resources Reports 103. FAO, Rome.

Kemper, W.D., Rosenau, R.C., 1986. Aggregate stability and size distribution. in: Klute, A. (Ed.), Methods of Soil Analysis. Part 1; 2nd ed. American Society of Agronomy and Soil Science Society of America, Madison, pp. 425-441.

Knicker, H., 2000. Biogenic nitrogen in soils as revealed by solid-state ${ }^{13} \mathrm{C}$ and ${ }^{15} \mathrm{~N}$ NMR spectroscopy. J. Environ. Qual. 29, 715-723.

Knicker, H., Totsche, K.U., Almendros, G., González-Vila, F.J. 2005. Condensation degree of burnt peat and plant residues and the reliability of solid-state VACP MAS ${ }^{13} \mathrm{C}$ NMR spectra obtained from pyrogenic humic material. Org. Geochem. 36, 1359-1377. 
Kögel-Knabner, I., 2002. The macromolecular organic composition of plant and microbial residues as inputs to soil organic matter. Soil Biol. Biochem. 34, $139-162$.

Kostiakov, A.N.,1932. On the dynamics of coefficient of water-percolation in soils and on the necessity of studying it from a dynamic point of view for purposes of amelioration. Transactions of the 6th Commission of the International Society of Soil Science, Groningen, pp.17-21.

Kruskal, J.B., 1964. Multidimensional scaling by optimizing goodness of fit to a nonmetric hypothesis. Psychometrika 29, 1-27.

Larson, W.E., Pierce, F.J. 1991. Conservation and enhancement of soil quality, in: International Board for Soil Research (Ed.), Evaluation for Sustainable Land Management in the Developing World. IBSRAM Proc. 12, vol. 2, Technical Papers, Bangkok, pp. 175-203.

Lei, S.A., 2004. Soil compaction from human trampling, biking and off-road motor vehicle activity in a blackbrush (Coleogyne ramosissima) shrubland. West N. Am. Naturalist 64, 125-130.

MacCarthy, P., Rice, J.A., 1985. Spectroscopic methods (other than NMR) for determining functionality in humic substances, in: Aiken, R.G., Mcknight, D.M., Wershaw, R.L., MacCarthy (Eds.), Humic Substances in Soil, Sediment and Water. Wiley, New York, pp. 527-559.

Masri, Z., Ryan, J., 2006. Soil organic matter and related physical properties in a Mediterranean wheat-based rotation trial. Soil Tillage Res. 87, 146-154.

Munsell, A.H., 1975. Directions for the Use of the Charts in the Munsell Book of Color. Munsell Color Company, Maryland.

Pansu, M., Gautheyrou, J., 2006. Quantification of humic compounds, in: Pansu M., Gautheyrou J. (Eds.), Handbook of Soil Analysis: Mineralogical, Organic and Inorganic Methods. Part 2. Springer, Berlin, pp. 371-397.

Piccolo, A., Mbagwu, J.S., 1999. Role of hydrophobic components of soil organic matter in soil aggregate stability. Soil Sci. Soc. Am. J. 63, 1801-1810.

Piper, C.S., 1950. Soil and Plant Analysis. University of Adelaide Hasell Press, Adelaide. 
Powers, R.F., Tiarks, A.E., Boyle, J.R., 1998. Assessing soil quality: practicable standards for sustainable forest productivity in the United States, in: Adams, M.B., Ramakrishna, K., Davidson, E.A. (Eds.). The Contribution of Soil Science to the Development and Implementation of Criteria and Indicators of Sustainable Forest Management. Soil Sci. Soc. Am. J., Special Publication 53, pp. 53-80.

Preston, C.M., 1996. Applications of NMR to soil organic matter analysis: history and prospects. Soil Sci. 161, 144-166.

Reynolds, W.D., Bowman, B.T., Drury, C.F., Tan, C.S., Lu, X., 2002. Indicators of good soil physical quality: density and storage parameters. Geoderma 110, $131-146$.

Reynolds, W.D., Drury, C.F., Tan, C.S., Fox, C.A., Yang, X.M., 2009. Use of indicators and pore volume-function characteristics to quantify soil physical quality. Geoderma 152, 252-263.

Rodeghiero, M., Rubio, S., Díaz-Pinés, E., Romanyá, J., Marañón-Jiménez, S., Levy, G.J., Fernández-Getino, A.P., Sebastià, M.T., Karyotis, T., Chiti, T., Sirca, C., Martins, A., Madeira, M., Zhiyanski, M., Gristina, L., Lamantia, T., 2011. Soil carbon in Mediterranean ecosystems and related management problems, in: Jandl, R., Rodeghiero, M., Olsson, M. (Eds.), Soil Carbon in Sensitive European Ecosystems: from Science to Land Management. Wiley. New York, pp.175-218.

Rodríguez-Murillo, J.C., 2001. Organic carbon content under different types of land use and soil in peninsular Spain. Biol. Fertil. Soils 33, 53-61.

Schnitzer, M., Khan, S.U., 1972. Humic Substances in the Environment. Dekker, New York.

Schnitzer, M., McArthur, D.F.E., Schulten, H.R., Kozak, L.M., Huang, P.M., 2006. Long-term cultivation effects on the quantity and quality of organic matter in selected Canadian prairie soils. Geoderma 130, 141-156.

Six, J., Elliott, E. T., Paustian, K., 2000. Soil structure and soil organic matter II. A normalized stability index and the effect of mineralogy. Soil Sci. Soc. Am. J. 64, 1042-1049. 
Skjemstad, J.O., Clarke, P., Taylor, J.A., Oades, J.M., Newman, R.H., 1994. The removal of magnetic materials from surface soils. A solid state ${ }^{13} \mathrm{C} \mathrm{CP} / \mathrm{MAS}$ NMR study. Soil Res. 32, 1215-1229.

Stevenson, F.J., 1994. Humus Chemistry: Genesis, Composition, Reactions. Wiley. New York.

Tinoco, P., Piedra Buena, A., Zancada, M.C., Sanz, J., Almendros, G., 2010. Biogeochemical proxies of anthropic impact in Mediterranean forest soils. Soil Use Manage. 26, 320-331.

Tisdall, J. M., Oades, J., 1982. Organic matter and water-stable aggregates in soils. J. Soil Sci 33, 141-163.

Topp, G.C., Reynolds, W.D., Cook, F.J., Kirby, J.M., Carter, M.R., 1997. Physical attributes of soil quality, in: Gregorich, E.G., Carter, M.R. (Eds.), Soil Quality for Crop Production and Ecosystem Health. Developments in Soil Science. Elsevier. New York, pp. 21-58.

Traina, S.J., Novak, J., Smeck, N.E., 1990. An ultraviolet absorbance method of estimating the percent aromatic carbon content of humic acids. J. Environ. Qual. 19, 151-153.

Virto, I., Gartzia-Bengoetxea, N., Fernandez-Ugalde, O., 2011. Role of organic matter and carbonates in soil aggregation estimated using laser diffractometry. Pedosphere 21, 566-572.

Walkley, A., Black, I.A., 1934. An examination of the Degtjareff method for determining soil organic matter and a proposed modification of the chromic acid titration method. Soil Sci. 37, 29-38.

Wilson, M.A., 1987. NMR Techniques and Applications in Geochemistry and Soil Chemistry. Pergamon, Oxford.

Wilson, M.A., 1990. Application of nuclear magnetic resonance spectroscopy to organic matter in whole soils, in: MacCarthy P., Clapp C.E., Malcolm R.L., Bloom P.R. (Eds.), Humic Substances in Soil and Crop Sciences: Selected Readings. American Society of Agronomy and Soil Science Society of America, Madison, pp. 221-260. 
Table 1. Location and general features of the soil sampled in Central Spain

\begin{tabular}{|c|c|c|c|c|c|c|c|c|c|c|c|c|}
\hline \multirow{2}{*}{ Soil } & \multirow{2}{*}{ Location } & \multirow{2}{*}{$\begin{array}{l}\text { Geographical } \\
\text { coordinates }\end{array}$} & \multirow{2}{*}{$\begin{array}{l}\text { Altitude } \\
\text { m a.s.l. }\end{array}$} & \multirow{2}{*}{$\begin{array}{l}\text { Physiographic } \\
\text { unit }\end{array}$} & \multirow{2}{*}{ Parent rock } & \multicolumn{3}{|c|}{ Climatic features } & \multirow{2}{*}{ Vegetation } & \multirow{2}{*}{ Soil use } & \multirow{2}{*}{$\begin{array}{l}\text { Humus type } \\
\text { (Duchaufour, 1975) }\end{array}$} & \multirow{2}{*}{$\begin{array}{l}\text { Soil classification } \\
\text { (IUSS-WRB, } \\
\text { 2007) }\end{array}$} \\
\hline & & & & & & $P(\mathrm{~mm})$ & $T\left({ }^{\circ} \mathrm{C}\right)$ & $\operatorname{PET}(\mathrm{mm})$ & & & & \\
\hline A1 & Parla (Madrid) & $\begin{array}{l}40^{\circ} 15^{\prime} 34 " \mathrm{~N} \\
3^{\circ} 45^{\prime} 05^{\prime \prime} \mathrm{W}\end{array}$ & 683 & Monadnock & $\begin{array}{l}\text { Limestones, } \\
\text { marlstones and } \\
\text { sepiolite }\end{array}$ & 445 & 14.2 & 785 & $\begin{array}{l}\text { Brushwood + } \\
\text { herbaceous }\end{array}$ & Abandoned & Calcic mull & Calcic Kastanozen \\
\hline A2 & $\begin{array}{l}\text { Cantoblanco } \\
\text { (Madrid) }\end{array}$ & $\begin{array}{l}40^{\circ} 33^{\prime} 8 " \mathrm{~N} \\
3^{\circ} 41^{\prime} 22^{\prime \prime} \mathrm{W}\end{array}$ & 731 & Moorland & Arkoses & 531 & 14.6 & 807 & $\begin{array}{l}\text { Brushwood + } \\
\text { herbaceous }\end{array}$ & Abandoned & Calcic mull & Haplic Luvisol \\
\hline A3 & $\begin{array}{l}\text { Santa Olalla } \\
\text { (Toledo) }\end{array}$ & $\begin{array}{l}40^{\circ} 3^{\prime} 18^{\prime \prime N} \\
4^{\circ} 25^{\prime} 57^{\prime \prime} \mathrm{W}\end{array}$ & 463 & Hillock & Arkoses & 553 & 15.4 & 821 & $\begin{array}{l}\text { Brushwood + } \\
\text { herbaceous }\end{array}$ & Abandoned & Calcic mull & Cutanic Luvisol \\
\hline $\mathrm{C} 1$ & Villacañas (Toledo) & $\begin{array}{l}39^{\circ} 37^{\prime} 14 " \mathrm{~N} \\
3^{\circ} 17^{\prime} 55^{\prime \prime} \mathrm{W}\end{array}$ & 680 & Fluvial terrace & $\begin{array}{l}\text { Limestones and } \\
\text { quartzites }\end{array}$ & 459 & 14.0 & 771 & Vineyard & Agricultural & Calcic mull & Petric Calcisol \\
\hline $\mathrm{C} 2$ & $\begin{array}{l}\text { Santa Olalla } \\
\text { (Toledo) }\end{array}$ & $\begin{array}{c}40^{\circ} 4^{\prime} 7 " \mathrm{~N} \\
4^{\circ} 25^{\prime} 22 " \mathrm{~W}\end{array}$ & 473 & Alluvial plain & $\begin{array}{l}\text { Mudstones and } \\
\text { marls }\end{array}$ & 553 & 15.4 & 821 & Cereal crop & Agricultural & Calcic mull & Calcic Vertisol \\
\hline $\mathrm{C} 3$ & $\begin{array}{l}\text { Manzanares } \\
\text { (Ciudad Real) }\end{array}$ & $\begin{array}{l}38^{\circ} 57^{\prime} 20 " \mathrm{~N} \\
3^{\circ} 24^{\prime} 19^{\prime \prime} \mathrm{W}\end{array}$ & 673 & Alluvial plain & $\begin{array}{l}\text { Limestones and } \\
\text { quartzites }\end{array}$ & 422 & 14.2 & 797 & Vineyard & Agricultural & Calcic mull & Petric Calcisol \\
\hline F1 & $\begin{array}{l}\text { Guadalix de la } \\
\text { Sierra (Madrid) }\end{array}$ & $\begin{array}{l}40^{\circ} 45^{\prime} 35 " \mathrm{~N} \\
3^{\circ} 41^{\prime} 9 " \mathrm{~W}\end{array}$ & 940 & Hillside & Granites & 692 & 12.4 & 731 & Quercus + grassland & Livestock & $\begin{array}{l}\text { Forest } \\
\text { oligotrophic mull }\end{array}$ & Leptic Cambisol \\
\hline F2 & Rascafría (Madrid) & $\begin{array}{l}40^{\circ} 54^{\prime 2} 27 " \mathrm{~N} \\
3^{\circ} 53^{\prime} 46 " \mathrm{~W}\end{array}$ & 1187 & Hillside & Gneisses & 895 & 10.1 & 631 & $\begin{array}{l}\text { Quercus }+ \\
\text { Juniperus }+ \text { Taxus }\end{array}$ & $\begin{array}{l}\text { Forest (protected } \\
\text { area) }\end{array}$ & $\begin{array}{l}\text { Forest } \\
\text { eutrophic mull }\end{array}$ & Haplic Cambisol \\
\hline F3 & Rascafŕía (Madrid) & $\begin{array}{l}40^{\circ} 53^{\prime} 35^{\prime \prime N} \\
3^{\circ} 53^{\prime} 33^{\prime \prime} \mathrm{W}\end{array}$ & 1185 & Foothill & Dolomites & & 10.1 & 631 & Quercus + grassland & Livestock & $\begin{array}{l}\text { Forest } \\
\text { eutrophic mull }\end{array}$ & Mollic Leptosol \\
\hline $\mathrm{R} 1$ & $\begin{array}{l}\text { Bustarviejo } \\
\text { (Madrid) }\end{array}$ & $\begin{array}{l}40^{\circ} 51^{\prime} 41 " \mathrm{~N} \\
3^{\circ} 44^{\prime} 4 " \mathrm{~W}\end{array}$ & 1316 & Hillside & Gneiss and schists & 732 & 10.8 & 692 & $\begin{array}{l}\text { Quercus + Pinus + } \\
\text { Juniperus }\end{array}$ & $\begin{array}{l}\text { Forest (protected } \\
\text { area) }\end{array}$ & $\begin{array}{l}\text { Forest eutrophic } \\
\text { mull }\end{array}$ & Haplic Cambisol \\
\hline $\mathrm{R} 2$ & Valdelatas (Madrid) & $\begin{array}{l}40^{\circ} 32^{\prime} 09 " \mathrm{~N} \\
3^{\circ} 40^{\prime} 53^{\prime \prime} \mathrm{W}\end{array}$ & 714 & Fluvial terrace & Arkoses & 531 & 14.6 & 807 & Quercus + Pinus & $\begin{array}{l}\text { Forest } \\
\text { (recreational use) }\end{array}$ & Calcic mull & Calcic Luvisol \\
\hline H1 & $\begin{array}{l}\text { Rascafría-Peñalara } \\
\text { (Madrid) }\end{array}$ & $\begin{array}{l}40^{\circ} 50^{\prime} 2 " \mathrm{~N} \\
3^{\circ} 57^{\prime} 26^{\prime \prime} \mathrm{W}\end{array}$ & 2030 & Hillside & Gneisses & 1170 & 6.4 & 520 & Herbaceous & Livestock & $\begin{array}{l}\text { Oligotrophic } \\
\text { anmoor }\end{array}$ & Hemic Histosol \\
\hline $\mathrm{H} 2$ & $\begin{array}{l}\text { Rascafría-Peñalara } \\
\text { (Madrid) }\end{array}$ & $\begin{array}{l}40^{\circ} 50^{\prime} 17 " \mathrm{~N} \\
3^{\circ} 57^{\prime} 13 " \mathrm{~W}\end{array}$ & 1964 & Hillside & Gneisses & 1123 & 6.8 & 531 & $\begin{array}{l}\text { Herbaceous }+ \\
\text { mosses and Carex }\end{array}$ & $\begin{array}{l}\text { Forest (protected } \\
\text { area) }\end{array}$ & $\begin{array}{l}\text { Oligotrophic } \\
\text { anmoor }\end{array}$ & Fibric Histosol \\
\hline $\mathrm{H} 3$ & Rascafŕ́a (Madrid) & $\begin{array}{l}40^{\circ} 54 ' 39 " \mathrm{~N} \\
3^{\circ} 51^{\prime} 55^{\prime \prime W}\end{array}$ & 1127 & Alluvial plain & $\begin{array}{l}\text { Silts, sands and } \\
\text { conglomerates }\end{array}$ & 895 & 10.1 & 631 & Herbaceous & $\begin{array}{l}\text { Forest (protected } \\
\text { area) }\end{array}$ & Calcic anmoor & Rheic Histosol \\
\hline
\end{tabular}

$P$ : mean annual precipitation; $T$ : mean annual temperature; $P E T$ : mean annual potential evapotranspiration. 
Table 2. Main physical and chemical properties of soils (A horizons) developed in Mediterranean ecosystems of Central Spain ${ }^{\mathrm{a}}$

\begin{tabular}{|c|c|c|c|c|c|c|c|c|c|c|c|c|c|c|}
\hline Sample & Al & A2 & A3 & $\mathrm{C} 1$ & $\mathrm{C} 2$ & $\mathrm{C} 3$ & $\mathrm{~F} 1$ & $\mathrm{~F} 2$ & F3 & $\mathrm{R} 1$ & R2 & H1 & $\mathrm{H} 2$ & $\mathrm{H} 3$ \\
\hline Sampling depth (cm) & 0.35 & $0-8$ & $0-20$ & $0-30$ & $0-25$ & $0-40$ & $0-15$ & $0-10$ & $0-18$ & $0-15$ & $0-10$ & $15-35$ & $10-20$ & $15-35$ \\
\hline $\begin{array}{l}\text { Soil colour (dry) } \\
\text { (Munsell, 1975) }\end{array}$ & $\begin{array}{r}10 \mathrm{YR} \\
6 / 2\end{array}$ & $\begin{array}{r}10 \mathrm{YR} \\
6 / 2\end{array}$ & $\begin{array}{r}10 \mathrm{YR} \\
5 / 3\end{array}$ & $\begin{array}{r}7.5 \mathrm{YR} \\
5 / 4\end{array}$ & $\begin{array}{r}2.5 \mathrm{Y} \\
6 / 2\end{array}$ & $\begin{array}{r}7.5 \mathrm{YR} \\
5 / 4\end{array}$ & $\begin{array}{r}10 \mathrm{YR} \\
5 / 2\end{array}$ & $\begin{array}{r}10 \mathrm{YR} \\
5 / 2\end{array}$ & $\begin{array}{r}10 \mathrm{YR} \\
4 / 3\end{array}$ & $\begin{array}{r}10 \mathrm{YR} \\
4 / 3\end{array}$ & $\begin{array}{r}10 \mathrm{YR} \\
5 / 3\end{array}$ & $\begin{array}{r}10 \mathrm{YR} \\
3 / 2\end{array}$ & $\begin{array}{r}7.5 \mathrm{YR} \\
3 / 2\end{array}$ & $\begin{array}{r}7.5 \mathrm{YR} \\
3 / 2\end{array}$ \\
\hline $\begin{array}{r}\text { Soil colour (moist) } \\
\text { (Munsell, 1975) }\end{array}$ & $\begin{array}{r}10 \mathrm{YR} \\
3 / 3\end{array}$ & $\begin{array}{r}10 \mathrm{YR} \\
3 / 2\end{array}$ & $\begin{array}{r}10 \mathrm{YR} \\
3 / 4\end{array}$ & $\begin{array}{r}5 \mathrm{YR} \\
3 / 3\end{array}$ & $\begin{array}{r}10 \mathrm{YR} \\
3 / 2\end{array}$ & $\begin{array}{r}7.5 \mathrm{YR} \\
3 / 4\end{array}$ & $\begin{array}{r}7.5 \mathrm{YR} \\
3 / 2\end{array}$ & $\begin{array}{r}5 \mathrm{YR} \\
3 / 2\end{array}$ & $\begin{array}{r}7.5 \mathrm{YR} \\
3 / 2\end{array}$ & $\begin{array}{l}5 \mathrm{YR} \\
2.5 / 1\end{array}$ & $\begin{array}{r}7.5 \mathrm{YR} \\
3 / 2\end{array}$ & $\begin{array}{l}5 \mathrm{YR} \\
2.5 / 1\end{array}$ & $\begin{array}{r}10 \mathrm{YR} \\
2 / 1\end{array}$ & $\begin{array}{l}5 \mathrm{YR} \\
2.5 / 2\end{array}$ \\
\hline Total sand $\left(2-0.02 \mathrm{~mm} ; \mathrm{g} \cdot 100 \mathrm{~g}^{-1}\right)$ & 39 & 75 & 60 & 59 & 12 & 53 & 38 & 62 & & 54 & 63 & 31 & 55 & 12 \\
\hline Silt $\left(0.02-0.002 \mathrm{~mm} ; \mathrm{g} \cdot 100^{-1}\right)$ & 30 & 8 & 20 & 16 & 40 & 23 & 41 & 18 & 19 & 29 & 19 & 34 & 21 & 53 \\
\hline Clay $\left(<0.002 \mathrm{~mm} ; \mathrm{g} \cdot 100 \mathrm{~g}^{-1}\right)$ & 31 & 17 & 20 & 25 & 48 & 24 & 21 & 20 & 22 & 17 & 18 & 35 & 24 & 35 \\
\hline $\mathrm{pH}$ in $\mathrm{H}_{2} \mathrm{O}(1: 2.5, \mathrm{w}: \mathrm{w})$ & 8.4 & 7.3 & 7.2 & 8.8 & 8.2 & 8.6 & 5.5 & 6.1 & 8.1 & 5.9 & 6.9 & 5.2 & 5.0 & 5.3 \\
\hline $\operatorname{EC}(1: 5, w: w)\left(d S \cdot m^{-1}\right)$ & 0.17 & 0.20 & 0.16 & 0.10 & 0.16 & 0.12 & 0.03 & 0.10 & 0.10 & 0.06 & 0.05 & 0.10 & 0.10 & 0.20 \\
\hline Total organic carbon $\left(\mathrm{g} \cdot 100 \mathrm{~g}^{-1}\right)$ & 2.00 & 1.84 & 2.72 & 0.67 & 0.79 & 0.93 & 7.38 & 4.71 & 2.73 & 3.63 & 1.59 & 23.37 & 20.60 & 22.60 \\
\hline Kjeldahl nitrogen $\left(\mathrm{g} \cdot 100 \mathrm{~g}^{-1}\right)$ & 0.20 & 0.16 & 0.20 & 0.06 & 0.08 & 0.08 & 0.44 & 0.26 & 0.18 & 0.29 & 0.11 & 1.30 & 12.20 & 12.90 \\
\hline Soil $\mathrm{C} / \mathrm{N}$ ratio & 10 & 12 & 14 & 11 & 10 & 11 & 17 & 18 & 16 & 13 & 15 & 18 & 17 & 18 \\
\hline Total $\mathrm{CaCO}_{3}\left(\mathrm{~g} \cdot 100 \mathrm{~g}^{-1}\right)$ & 6.8 & $<0.01$ & $<0.01$ & 17.2 & 18.8 & 13.9 & $<0.01$ & $<0.01$ & 17.4 & $<0.01$ & $<0.01$ & $<0.01$ & $<0.01$ & $<0.01$ \\
\hline Active carbonate $\left(\mathrm{g} \cdot 100 \mathrm{~g}^{-1}\right)$ & 2.0 & $<0.01$ & $<0.01$ & 9.1 & 3.6 & 6.8 & $<0.01$ & $<0.01$ & $<0.01$ & $<0.01$ & $<0.01$ & $<0.01$ & $<0.01$ & $<0.01$ \\
\hline Exchangeable $\mathrm{Na}^{+}\left(\mathrm{cmol}_{\mathrm{c}} \cdot \mathrm{kg}^{-1}\right.$ soil $)$ & 0.3 & 0.4 & 0.1 & 0.2 & 0.2 & 0.2 & 0.2 & 0.1 & 0.1 & 0.2 & 0.1 & 0.4 & 0.6 & 0.6 \\
\hline Exchangeable $\mathrm{K}^{+}\left(\mathrm{cmol}_{\mathrm{c}} \cdot \mathrm{kg}^{-1}\right.$ soil $)$ & 0.7 & 0.6 & 1.7 & 0.6 & 1.5 & 1.1 & 0.9 & 1.0 & 0.3 & 0.6 & 0.3 & 0.2 & 0.3 & 0.2 \\
\hline Exchangeable $\mathrm{Ca}^{2+}\left(\mathrm{cmol}_{\mathrm{c}} \cdot \mathrm{kg}^{-1}\right.$ soil $)$ & 34.1 & 7.8 & 8.8 & 54.9 & 45.4 & 47 & 4.2 & 6.9 & 13.7 & 5 & 7.4 & 1.5 & 7.7 & 25.6 \\
\hline Exchangeable $\mathrm{Mg}^{2+}\left(\mathrm{cmol}_{\mathrm{c}} \cdot \mathrm{kg}^{-1}\right.$ soil $)$ & 5.4 & 1.5 & 2.5 & 1.1 & 4.0 & 2.2 & 2.3 & 2.6 & 6.2 & 1.5 & 2.1 & 0.8 & 1.5 & 6.6 \\
\hline CEC $\left(\mathrm{cmol}_{\mathrm{c}} \cdot \mathrm{kg}^{-1}\right.$ soil $)$ & 45.9 & 13.4 & 23.4 & 19.8 & 63.2 & 19.3 & 24.6 & 25.7 & 25.1 & 23.0 & 15.8 & 65.1 & 58.2 & 88.7 \\
\hline Base saturation (\%) & 89 & 76 & 56 & 100 & 81 & 100 & 31 & 41 & 82 & 32 & 63 & 3 & 10 & 33 \\
\hline
\end{tabular}

${ }^{\text {a }}$ Sample references refer to Table $1 . \mathrm{EC}=$ electrical conductivity; $\mathrm{CEC}=$ cation exchange capacity. 
Table 3. Physical descriptors of soil quality determined in Mediterranean ecosystems in Central Spain ${ }^{\mathrm{a}}$

\begin{tabular}{|c|c|c|c|c|c|c|c|c|c|c|c|c|c|c|}
\hline Sample & A1 & A2 & A3 & $\mathrm{C} 1$ & $\mathrm{C} 2$ & $\mathrm{C} 3$ & $\mathrm{~F} 1$ & $\mathrm{~F} 2$ & F3 & $\mathrm{R} 1$ & $\mathrm{R} 2$ & H1 & $\mathrm{H} 2$ & $\mathrm{H} 3$ \\
\hline Sampling depth $(\mathrm{cm})$ & $0-35$ & $0-8$ & $0-20$ & $0-30$ & $0-25$ & $0-40$ & $0-15$ & $0-10$ & $0-18$ & $0-15$ & $0-10$ & $15-35$ & $10-20$ & $15-35$ \\
\hline Particle density $\left(\mathrm{g} \cdot \mathrm{cm}^{-3}\right)$ & 2.03 & 2.17 & 2.38 & 2.27 & 2.38 & 2.36 & 2.27 & 2.13 & 2.22 & 2.17 & 2.33 & 1.69 & 1.55 & 1.49 \\
\hline Bulk density $\left(\mathrm{g} \cdot \mathrm{cm}^{-3}\right)$ & 1.33 & 1.36 & 1.41 & 1.72 & 1.45 & 1.63 & 0.96 & 1.01 & 1.19 & 0.96 & 1.42 & 0.78 & 0.53 & 0.71 \\
\hline Porosity (\%) & 35 & 38 & 41 & 24 & 39 & 31 & 58 & 52 & 46 & 56 & 39 & 54 & 66 & 52 \\
\hline $\operatorname{SSI}\left(\mathrm{g} \cdot 100 \mathrm{~g}^{-1}\right)$ & 97.1 & 92.2 & 83.7 & 89.4 & 60.6 & 33.5 & 96.4 & 97.7 & 95.4 & 97.9 & 63.0 & 72.5 & 67.4 & 84.5 \\
\hline FC (w:w, g. $\left.100 \mathrm{~g}^{-1}\right)$ & 24.3 & 7.3 & 15.5 & 10.3 & 32.7 & 13.4 & 28.6 & 17.0 & 12.6 & 12.4 & 8.2 & 61.8 & 58.9 & 83.5 \\
\hline PWP (w:w, g· $\left.100 \mathrm{~g}^{-1}\right)$ & 17.4 & 2.5 & 5.9 & 4.4 & 20.6 & 7.2 & 14.8 & 7.5 & 4.1 & 4.4 & 2.0 & 47.9 & 41.6 & 69.3 \\
\hline AWC (w:w, g. $\left.100 g^{-1}\right)$ & 7.0 & 4.8 & 9.6 & 5.9 & 12.1 & 6.2 & 13.8 & 9.5 & 8.5 & 7.9 & 6.2 & 13.9 & 17.3 & 14.2 \\
\hline FAC (v:v, \%) & 7.6 & 74.0 & 46.8 & 26.2 & 0.0 & 29.4 & 52.7 & 66.9 & 67.4 & 78.8 & 70.3 & 0.0 & 11.4 & 0.0 \\
\hline $\operatorname{Ir}\left(\mathbf{m m} \cdot \min ^{-1}\right)$ & 5.4 & 10.0 & 3.0 & 7.4 & 4.0 & 4.2 & 0.8 & 2.4 & 2.2 & 9.9 & 2.9 & n.d. & n.d. & n.d. \\
\hline Parameter $c\left(\mathbf{m m} \cdot \mathbf{m i n}^{-1}\right)$ & 9.5 & 29.9 & 7.2 & 10.7 & 7.0 & 7.9 & 2.8 & 7.1 & 4.1 & 20.4 & 5.5 & n.d. & n.d. & n.d. \\
\hline Parameter $a$ & 0.37 & 0.49 & 0.58 & 0.16 & 0.22 & 0.36 & 0.55 & 0.53 & 0.35 & 0.27 & 0.33 & n.d. & n.d. & n.d. \\
\hline
\end{tabular}

${ }^{\text {a }}$ Sample references refer to Table 1 . SSI = structural stability index; FC = water content at field capacity $(-0.03 \mathrm{MPa})$; PWP = water content at the permanent wilting point $(-1.5 \mathrm{MPa}) ; \mathrm{AWC}=$ available water capacity; $\mathrm{FAC}=$ field air capacity; $I r$ = average infiltration rate after 60 minutes; n.d. = not determined (unreliable experimental results in this soil group). 
Table 4. Intensity distribution in the solid-state ${ }^{13} \mathrm{C}$ NMR spectra (\%) of HF-treated samples of Mediterranean soils from Central Spain

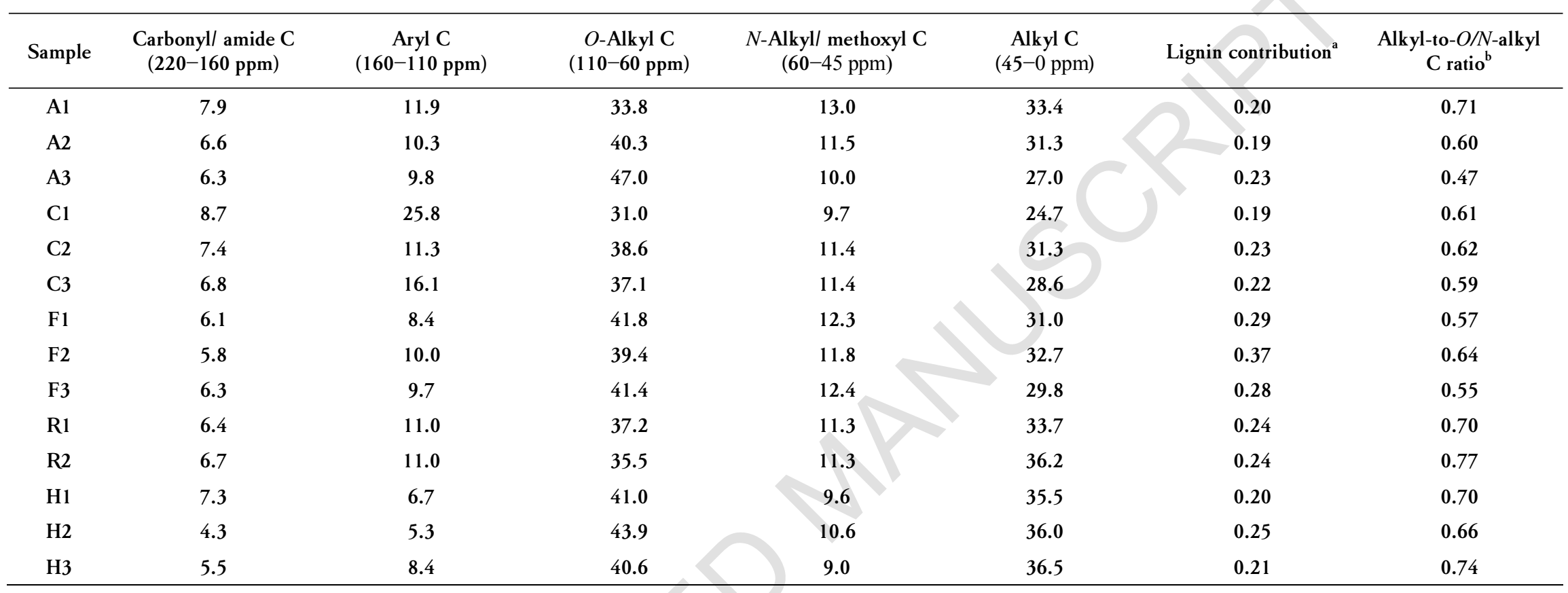

${ }^{\mathrm{a}}$ Lignin contribution $=$ substituted aryl C $(160-140 \mathrm{ppm}) /$ olefinic and non-substituted aryl C $(140-110 \mathrm{ppm})$.

${ }^{\text {b }}$ Alkyl-to- $O / N$-alkyl C ratio $=$ alkyl C $(45-0 \mathrm{ppm}) /[O$-alkyl C $(110-60 \mathrm{ppm})+N$-alkyl/methoxyl C $(60-45 \mathrm{ppm})]$. 
Table 5. Distribution of soil organic carbon in different organic fractions

\begin{tabular}{|c|c|c|c|c|c|c|}
\hline Sample $^{a}$ & & Free lipids & f-POM & FA & HA & Humin \\
\hline \multirow[t]{2}{*}{ Al } & (1) & 0.002 & 0.030 & 0.18 & 0.31 & 1.47 \\
\hline & (2) & 0.1 & 1.5 & 9.0 & 15.6 & 73.8 \\
\hline \multirow[t]{2}{*}{$\mathrm{A} 2$} & (1) & 0.003 & 0.103 & 0.33 & 0.36 & 1.05 \\
\hline & (2) & 0.2 & 5.6 & 17.7 & 19.5 & 57.0 \\
\hline \multirow[t]{2}{*}{ A3 } & (1) & 0.010 & 0.236 & 0.30 & 0.82 & 1.36 \\
\hline & (2) & 0.4 & 8.7 & 10.9 & 30.0 & 50.1 \\
\hline \multirow[t]{2}{*}{$\mathrm{C} 1$} & (1) & 0.002 & 0.001 & 0.09 & 0.15 & 0.42 \\
\hline & (2) & 0.3 & 0.2 & 13.5 & 23.1 & 62.9 \\
\hline \multirow[t]{2}{*}{$\mathrm{C} 2$} & (1) & 0.001 & 0.002 & 0.09 & 0.21 & 0.48 \\
\hline & (2) & 0.1 & 0.3 & 11.8 & 26.8 & 60.8 \\
\hline \multirow[t]{2}{*}{ C3 } & (1) & 0.002 & 0.011 & 0.15 & 0.27 & 0.51 \\
\hline & (2) & 0.2 & 1.2 & 15.8 & 28.3 & 54.4 \\
\hline \multirow[t]{2}{*}{ F1 } & (1) & 0.015 & 0.466 & 0.71 & 1.90 & 4.29 \\
\hline & (2) & 0.2 & 6.3 & 9.7 & 25.8 & 58.1 \\
\hline \multirow[t]{2}{*}{ F2 } & (1) & 0.007 & 0.375 & 0.65 & 1.35 & 2.33 \\
\hline & (2) & 0.1 & 8.0 & 13.9 & 28.6 & 49.4 \\
\hline \multirow[t]{2}{*}{ F3 } & (1) & 0.001 & 0.226 & 0.29 & 0.61 & 1.61 \\
\hline & (2) & 0.0 & 8.3 & 10.4 & 22.2 & 59.0 \\
\hline \multirow[t]{2}{*}{$\mathrm{R} 1$} & (1) & 0.004 & 0.200 & 0.61 & 1.13 & 1.69 \\
\hline & (2) & 0.1 & 5.5 & 16.9 & 31.0 & 46.5 \\
\hline \multirow[t]{2}{*}{$\mathrm{R} 2$} & (1) & 0.002 & 0.094 & 0.14 & 0.68 & 0.68 \\
\hline & (2) & 0.1 & 5.9 & 8.9 & 42.6 & 42.4 \\
\hline \multirow[t]{2}{*}{ H1 } & (1) & 0.013 & 0.957 & 3.15 & 6.10 & 13.14 \\
\hline & (2) & 0.1 & 4.1 & 13.5 & 26.1 & 56.2 \\
\hline \multirow[t]{2}{*}{$\mathrm{H} 2$} & (1) & 0.048 & 0.558 & 1.32 & 6.61 & 12.07 \\
\hline & (2) & 0.2 & 2.7 & 6.4 & 32.1 & 58.6 \\
\hline \multirow[t]{2}{*}{ H3 } & (1) & 0.131 & 1.796 & 1.36 & 10.71 & 8.60 \\
\hline & (2) & 0.6 & 7.9 & 6.0 & 47.4 & 38.1 \\
\hline
\end{tabular}

${ }^{a}$ Sample references refer to Table 1.

${ }^{(1)} \mathrm{g} \mathrm{C} \cdot\left(100 \mathrm{~g} \mathrm{soil}^{-1}\right)^{(2)} \mathrm{g} \mathrm{C} \cdot(100 \mathrm{~g} \mathrm{TOC})^{-1}$.

f-POM: free particulate organic matter (light fraction), FA: fulvic acid (soluble at acid and alkaline $\mathrm{pH}$ ), HA: humic acid (soluble at alkaline $\mathrm{pH}$, insoluble at acid $\mathrm{pH}$ ), Humin: insoluble at acid and alkaline $\mathrm{pH}$. 
Table 6. Elemental composition (ash-free basis) of humic acids from soils in Mediterranean ecosystems of central Spain

\begin{tabular}{|c|c|c|c|c|c|c|c|}
\hline \multirow[b]{2}{*}{ Sample } & \multicolumn{4}{|c|}{$\left(\mathrm{g} \cdot 100 \mathrm{~g}^{-1}\right)$} & \multirow[b]{2}{*}{$\mathrm{C} / \mathrm{N}$} & \multicolumn{2}{|c|}{ Atomic ratios } \\
\hline & C & $\mathrm{H}$ & $\mathrm{O}$ & $\mathrm{N}$ & & $\mathrm{H} / \mathrm{C}$ & $\mathrm{O} / \mathrm{C}$ \\
\hline Al & 55.7 & 4.9 & 34.7 & 4.7 & 11.8 & 1.05 & 0.47 \\
\hline A2 & 54.1 & 4.7 & 36.1 & 5.1 & 10.7 & 1.03 & 0.50 \\
\hline A3 & 52.5 & 6.7 & 37.5 & 3.3 & 15.9 & 1.54 & 0.54 \\
\hline $\mathrm{C} 1$ & 56.7 & 2.7 & 35.3 & 5.4 & 10.5 & 0.56 & 0.47 \\
\hline C2 & 55.7 & 4.0 & 34.9 & 5.3 & 10.5 & 0.85 & 0.47 \\
\hline C3 & 55.3 & 4.1 & 35.6 & 5.1 & 10.9 & 0.87 & 0.48 \\
\hline F1 & 56.7 & 6.8 & 31.8 & 4.6 & 14.3 & 1.44 & 0.42 \\
\hline F2 & 55.9 & 5.5 & 35.2 & 3.5 & 18.8 & 1.17 & 0.47 \\
\hline F3 & 54.6 & 5.2 & 36.3 & 3.9 & 16.5 & 1.14 & 0.50 \\
\hline R1 & 55.6 & 5.3 & 34.5 & 4.6 & 13.9 & 1.13 & 0.47 \\
\hline $\mathrm{R} 2$ & 57.3 & 5.0 & 34.0 & 3.8 & 17.6 & 1.04 & 0.45 \\
\hline H1 & 55.2 & 5.4 & 34.5 & 4.9 & 13.2 & 1.17 & 0.47 \\
\hline $\mathrm{H} 2$ & 57.7 & 5.7 & 33.0 & 3.5 & 19.1 & 1.19 & 0.43 \\
\hline $\mathrm{H} 3$ & 57.2 & 5.5 & 33.9 & 3.4 & 19.3 & 1.16 & 0.44 \\
\hline
\end{tabular}


Table 7. Spectroscopic data of humic acids from Mediterranean soils in Central Spain

\begin{tabular}{|c|c|c|c|c|c|c|c|c|c|c|c|c|c|c|c|}
\hline \multirow[b]{2}{*}{ Sample } & \multicolumn{3}{|c|}{$\begin{array}{l}\text { Optical density values in the visible } \\
\text { range (wavelength, } \mathrm{nm} \text { ) }\end{array}$} & \multicolumn{12}{|c|}{ Standardised intensities ${ }^{\mathrm{a}}$ of the bands measured in the second derivative of the infrared spectra (wavelength, $\mathrm{cm}^{-1}$ ) } \\
\hline & $\begin{array}{l}\mathrm{E}_{4}(465 \mathrm{~nm}, \\
\left.\mathrm{AU}^{*}\right)\end{array}$ & $\begin{array}{l}\mathrm{E}_{6}(665 \mathrm{~nm}, \\
\left.\mathrm{AU}^{*}\right)\end{array}$ & $\mathrm{E}_{4} / \mathrm{E}_{6}$ & 2920 & 1720 & 1640 & 1620 & 1540 & 1510 & 1460 & 1420 & 1330 & 1270 & $1510 / 2920$ & $1720 / 1510$ \\
\hline Al & 1.1 & 0.2 & 4.4 & 10.5 & 7.3 & 5.4 & 9.2 & 8.1 & 8.0 & 29.3 & 9.2 & 6.0 & 6.9 & 0.8 & 0.9 \\
\hline $\mathrm{A} 2$ & 0.6 & 0.1 & 5.0 & 12.9 & 4.0 & 6.1 & 10.3 & 4.9 & 7.9 & 28.6 & 7.4 & 5.1 & 12.8 & 0.6 & 0.5 \\
\hline $\mathrm{A} 3$ & 0.7 & 0.1 & 5.6 & 17.5 & 12.0 & 6.7 & 11.8 & 8.3 & 3.2 & 27.4 & 3.1 & 2.6 & 7.4 & 0.2 & 3.8 \\
\hline $\mathrm{C} 1$ & 2.1 & 0.5 & 4.1 & 6.5 & 8.6 & 3.9 & 1.6 & 32.9 & 21.0 & 14.8 & 1.7 & 5.7 & 3.3 & 3.2 & 0.4 \\
\hline $\mathrm{C} 2$ & 1.7 & 0.4 & 4.0 & 8.7 & 8.2 & 3.9 & 3.0 & 29.5 & 19.7 & 15.8 & 2.1 & 4.4 & 4.6 & 2.3 & 0.4 \\
\hline $\mathrm{C} 3$ & 1.4 & 0.3 & 4.5 & 17.4 & 6.5 & 4.0 & 3.9 & 17.8 & 13.6 & 21.7 & 5.6 & 3.5 & 5.8 & 0.8 & 0.5 \\
\hline $\mathrm{F} 1$ & 0.7 & 0.1 & 6.1 & 14.2 & 12.6 & 4.9 & 11.9 & 8.2 & 2.9 & 30.0 & 5.5 & 2.4 & 7.3 & 0.2 & 4.4 \\
\hline F2 & 0.7 & 0.1 & 6.4 & 14.5 & 10.6 & 4.1 & 11.2 & 6.5 & 1.7 & 32.1 & 7.0 & 5.1 & 7.3 & 0.1 & 6.3 \\
\hline F3 & 0.8 & 0.1 & 5.6 & 15.1 & 10.8 & 4.2 & 9.4 & 5.5 & 4.0 & 31.6 & 6.7 & 5.1 & 7.6 & 0.3 & 2.7 \\
\hline $\mathrm{R} 1$ & 1.1 & 0.2 & 4.8 & 15.5 & 14.3 & 5.2 & 11.2 & 6.0 & 4.8 & 26.2 & 4.9 & 4.5 & 7.4 & 0.3 & 3.0 \\
\hline $\mathrm{R} 2$ & 1.1 & 0.2 & 5.0 & 15.5 & 17.4 & 4.5 & 11.3 & 7.2 & 3.9 & 27.3 & 4.2 & 3.4 & 5.5 & 0.2 & 4.5 \\
\hline $\mathrm{H} 1$ & 1.1 & 0.2 & 4.8 & 18.0 & 12.6 & 6.0 & 12.9 & 5.8 & 5.5 & 25.5 & 4.9 & 3.4 & 5.4 & 0.3 & 2.3 \\
\hline $\mathrm{H} 2$ & 0.7 & 0.1 & 6.3 & 15.8 & 11.3 & 5.5 & 10.6 & 9.0 & 3.0 & 30.4 & 5.6 & 1.1 & 7.5 & 0.2 & 3.8 \\
\hline H3 & 0.8 & 0.1 & 7.3 & 16.7 & 13.0 & 4.6 & 10.9 & 7.4 & 1.9 & 31.0 & 5.8 & 2.1 & 6.6 & 0.1 & 6.8 \\
\hline
\end{tabular}

${ }^{*} \mathrm{AU}=$ absorption units.

${ }^{\text {a }}$ As total abundances, sum of all band intensities $=100$. 
Table 8. Significant $(P<0.05)$ linear correlation indices between variables used to assess soil physical quality and variables informing on the composition and properties of soil organic matter of the corresponding soils

\begin{tabular}{|c|c|c|c|c|c|c|c|c|c|}
\hline & & Porosity & FC & PWP & AWC & FAC & $\operatorname{Par} c^{1}$ & $\operatorname{Par} a^{1}$ & $\operatorname{Ir}^{1}$ \\
\hline \multirow{5}{*}{ 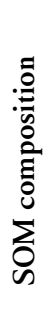 } & TOC & $0.68^{*}$ & $0.93^{*}$ & $0.92^{*}$ & $0.81^{*}$ & & & & \multirow{10}{*}{0.73} \\
\hline & Kjeldahl N & 0.54 & $0.82^{*}$ & $0.81^{*}$ & $0.68^{*}$ & & & & \\
\hline & Soil C/N ratio & $0.77^{*}$ & & & 0.63 & & & & \\
\hline & f-POM & & & & & 0.54 & & 0.70 & \\
\hline & FA & & -0.58 & -0.55 & -0.59 & & $0.77^{*}$ & & \\
\hline \multirow{5}{*}{ 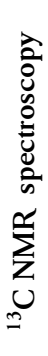 } & Carbonyl C & $-0.80^{*}$ & & & -0.59 & & & -0.71 & \\
\hline & Aryl C & $-0.80^{*}$ & & & -0.63 & & & -0.63 & \\
\hline & $O$-Alkyl C & 0.61 & & & & & & $0.75^{*}$ & \\
\hline & $N$-Alkyl/Methoxyl C & & -0.54 & -0.56 & & & & & \\
\hline & Alkyl C & 0.63 & 0.59 & 0.59 & & & & & \\
\hline
\end{tabular}

Only significant $(P<0.05)$ correlations indices are shown. Asterisks indicate $P<0.01$.

${ }^{1}$ Linear correlation models between soil organic matter features and infiltration parameters were carried out excluding Histosols.

FC = water content at field capacity $(-0.03 \mathrm{MPa})$; PWP = water content at the permanent wilting point $(-1.5 \mathrm{MPa})$; $\mathrm{AWC}=$ available water capacity; FAC = field air capacity; Par $a$ = parameter $a$ from Kostiakov equation; Par $b=$ parameter $b$ from Kostiakov equation; $I r=$ average infiltration rate after 60 minutes; TOC = total organic carbon; $\mathrm{f}-\mathrm{POM}$ = free particulate organic matter; FA: fulvic acid (soluble at acid and alkaline $\mathrm{pH})$. 
Table 9. Significant $(P<0.05)$ linear correlation indices between variables used to assess soil physical quality and spectroscopic features of HAs from the corresponding soils

\begin{tabular}{|c|c|c|c|c|c|c|c|}
\hline & Porosity & FC & PWP & AWC & FAC & $\operatorname{Par} c^{1}$ & $\operatorname{Par} a^{1} \quad I^{1}$ \\
\hline $\mathrm{E}_{4}$ & -0.62 & & & & & & $-0.87^{*}$ \\
\hline $\mathrm{E}_{4} / \mathrm{E}_{6}$ & $0.68^{*}$ & & & 0.56 & & & $0.80^{*}$ \\
\hline $1510 \mathrm{~cm}^{-1} \mathrm{IR}$ (aromatic $\mathrm{C}=\mathrm{C}$, lignin) & $-0.72^{*}$ & & & & & & -0.73 \\
\hline $1460 \mathrm{~cm}^{-1}$ IR (aliphatic C-H, lignin) & 0.62 & & & & & & 0.73 \\
\hline $1330 \mathrm{~cm}^{-1}$ IR (guaiacyl lignin groups) & -0.60 & -0.60 & -0.56 & $-0.72^{*}$ & & & \\
\hline $1270 \mathrm{~cm}^{-1}$ IR (syringyl lignin groups) & & & & & & 0.66 & 0.62 \\
\hline Aromaticity index & -0.66 & & & & & & -0.72 \\
\hline Oxidation index & 0.63 & & & & & & \\
\hline
\end{tabular}

Only significant $(P<0.05)$ correlations indices are shown. Asterisks indicate $P<0.01$.

${ }^{1}$ Linear correlation models between soil organic matter features and infiltration parameters were carried out excluding Histosols. Variable labels refer to Tables 3 and 7. 


\section{Figure 1}
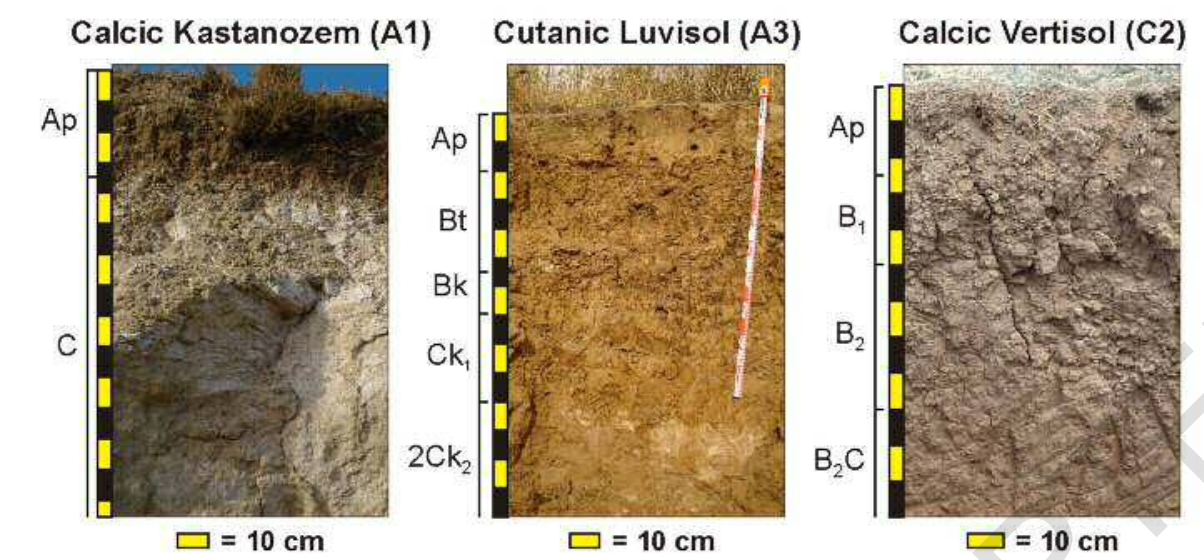

Petric Calcisol (C3)
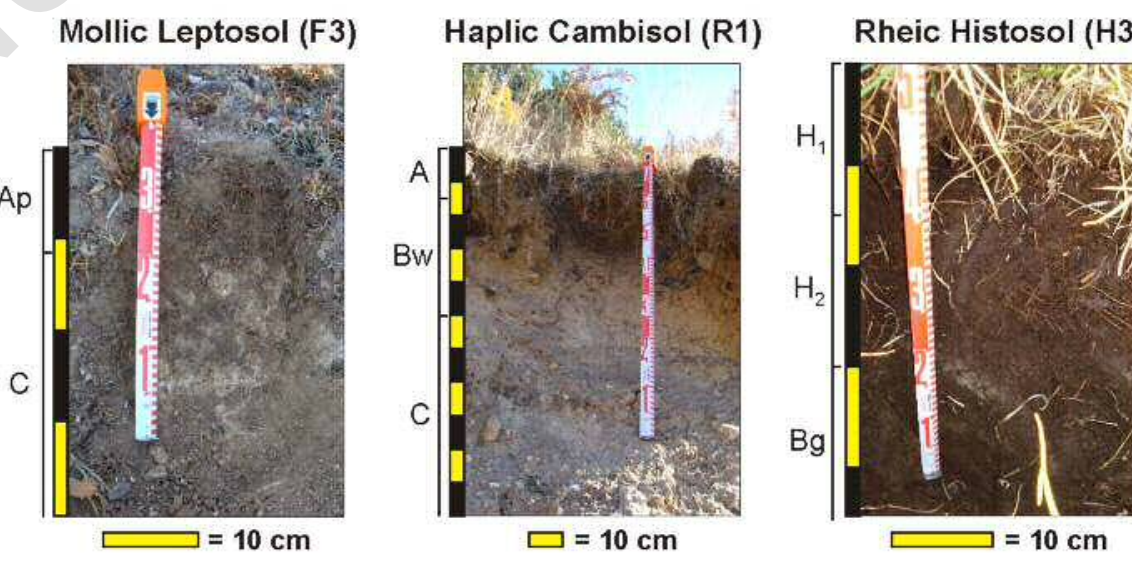
Figure 2

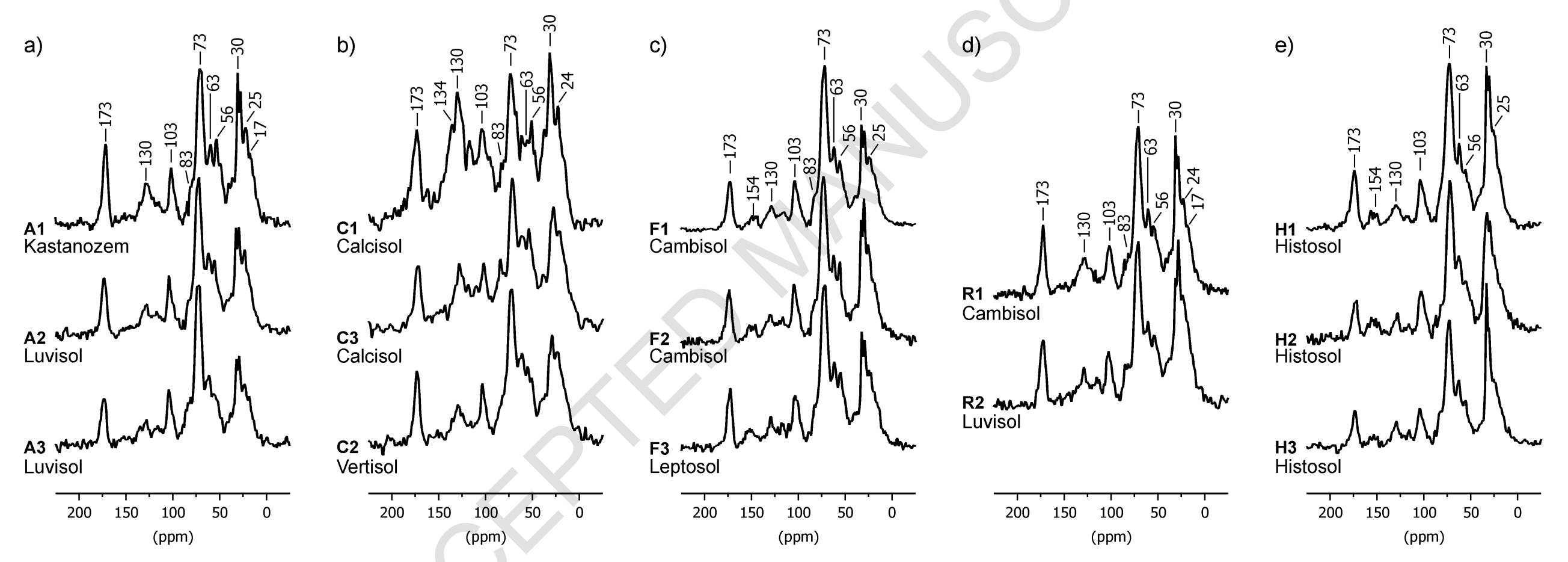




\section{Figure 3}
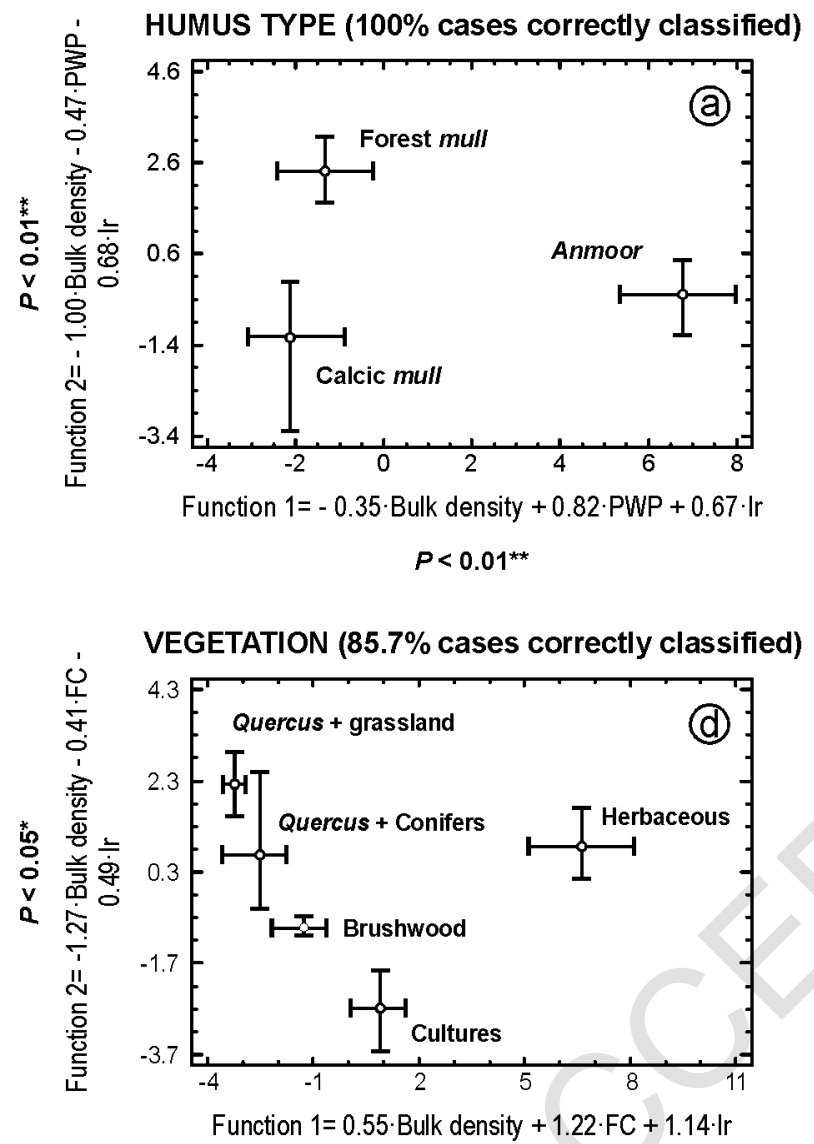

$P<0.01^{\star *}$
TOPOGRAPHY (92.9\% cases correctly classified)

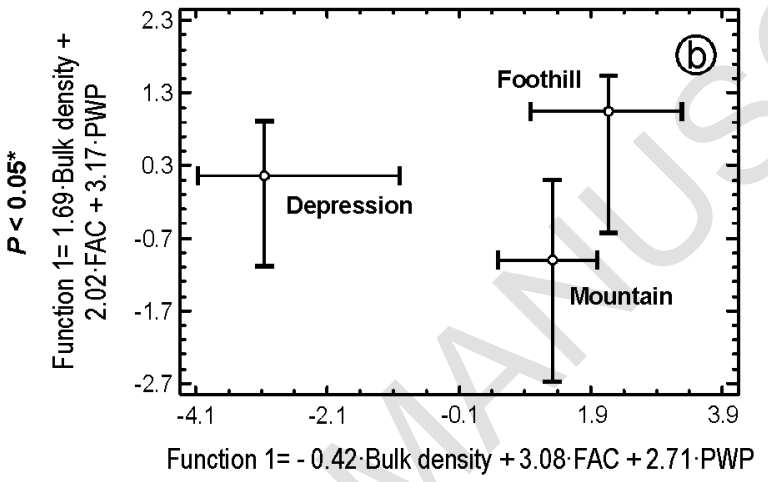

$$
P<0.01^{* *}
$$

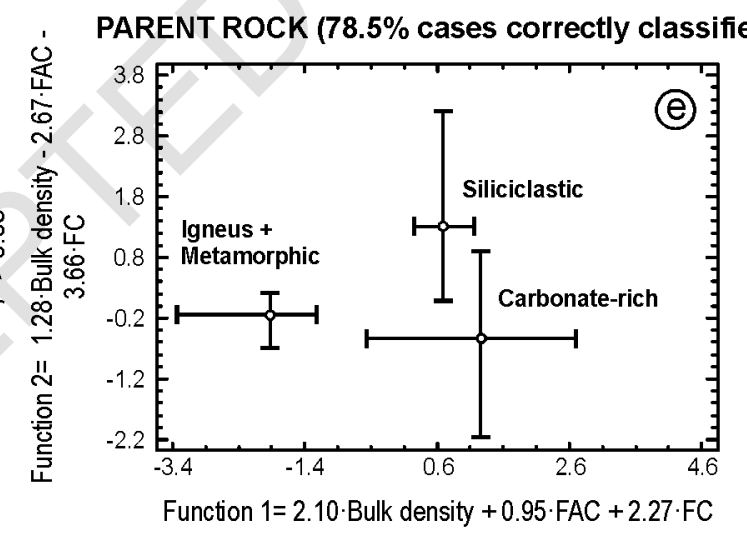

$P<0.01^{\text {** }}$
CLIMATE $(92.9 \%$ cases correctly classified)

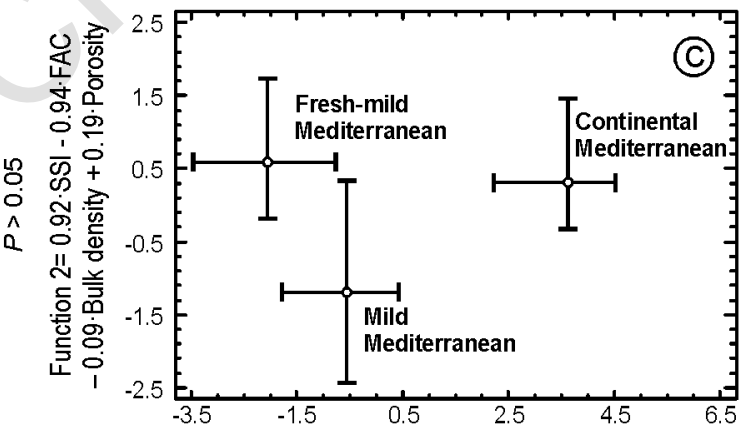

Function $1=1.55 \cdot \mathrm{SSI}-2.44 \cdot \mathrm{FAC}+3.93 \cdot$ Bulk density $+2.53 \cdot$ Porosity

$$
P<0.01^{\star *}
$$

SOIL USE $(78.6 \%$ cases correctly classified)

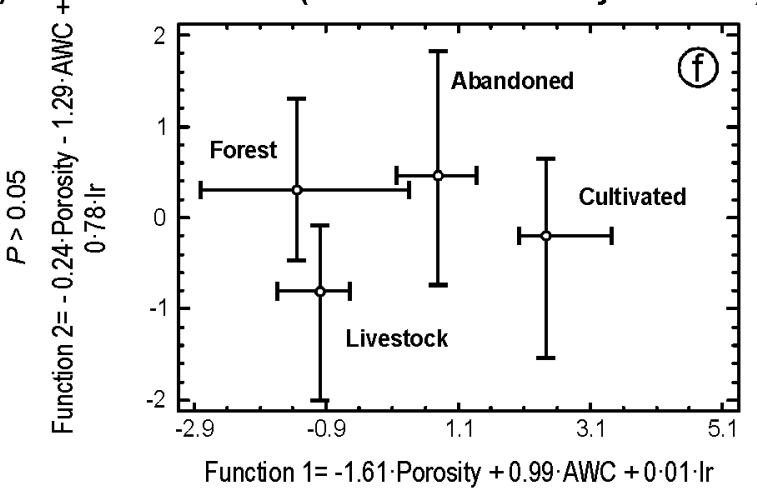

$P>0.05$ 


\section{Figure 4}

a) ${ }^{13} \mathrm{C}$ NMR data vs. physical properties

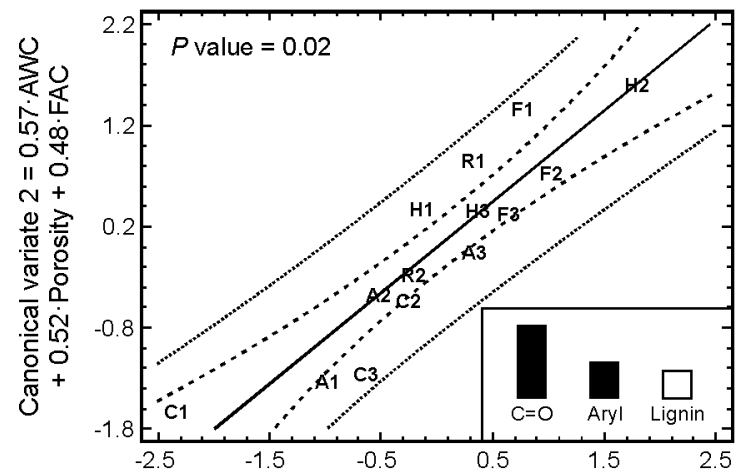

Canonical variate $1=-0.61 \cdot \mathrm{C}=\mathrm{O}-0.31 \cdot \mathrm{Aryl}$ $+0.24 \cdot$ Lignin

c) ${ }^{13} \mathrm{C}$ NMR data vs. soil water infiltration

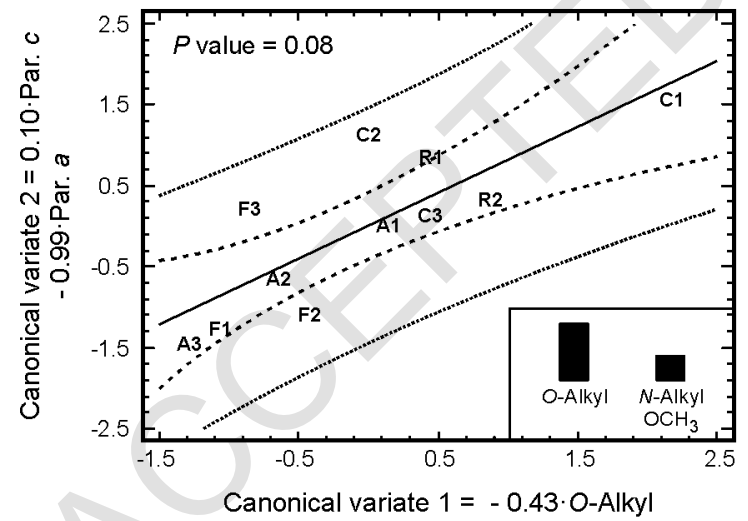

$-0.40 \cdot \mathrm{N}$-Alkyl/OCH${ }_{3}$

\section{b) HAs characteristics vs. physical properties}
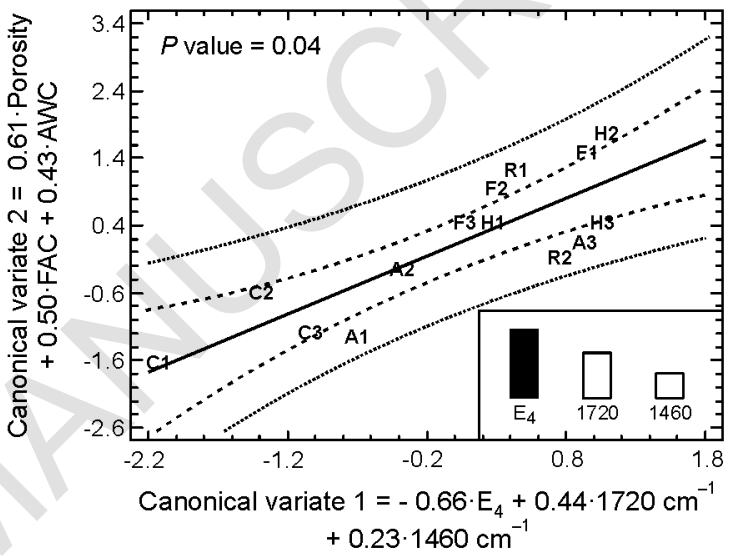

d) HAs characteristics vs. soil water infiltration

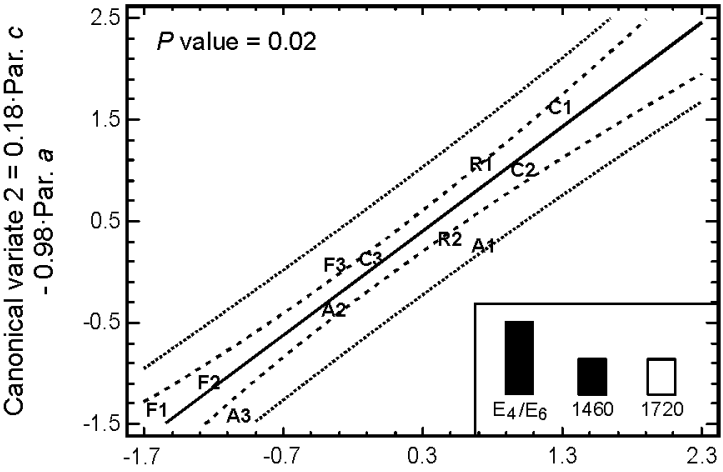

Canonical variate $1=-0.89 \cdot E_{4} / E_{6}-0.43 \cdot 1460 \mathrm{~cm}^{-1}$ $+0.43 \cdot 1720 \mathrm{~cm}^{-1}$ 


\section{Figure 5}

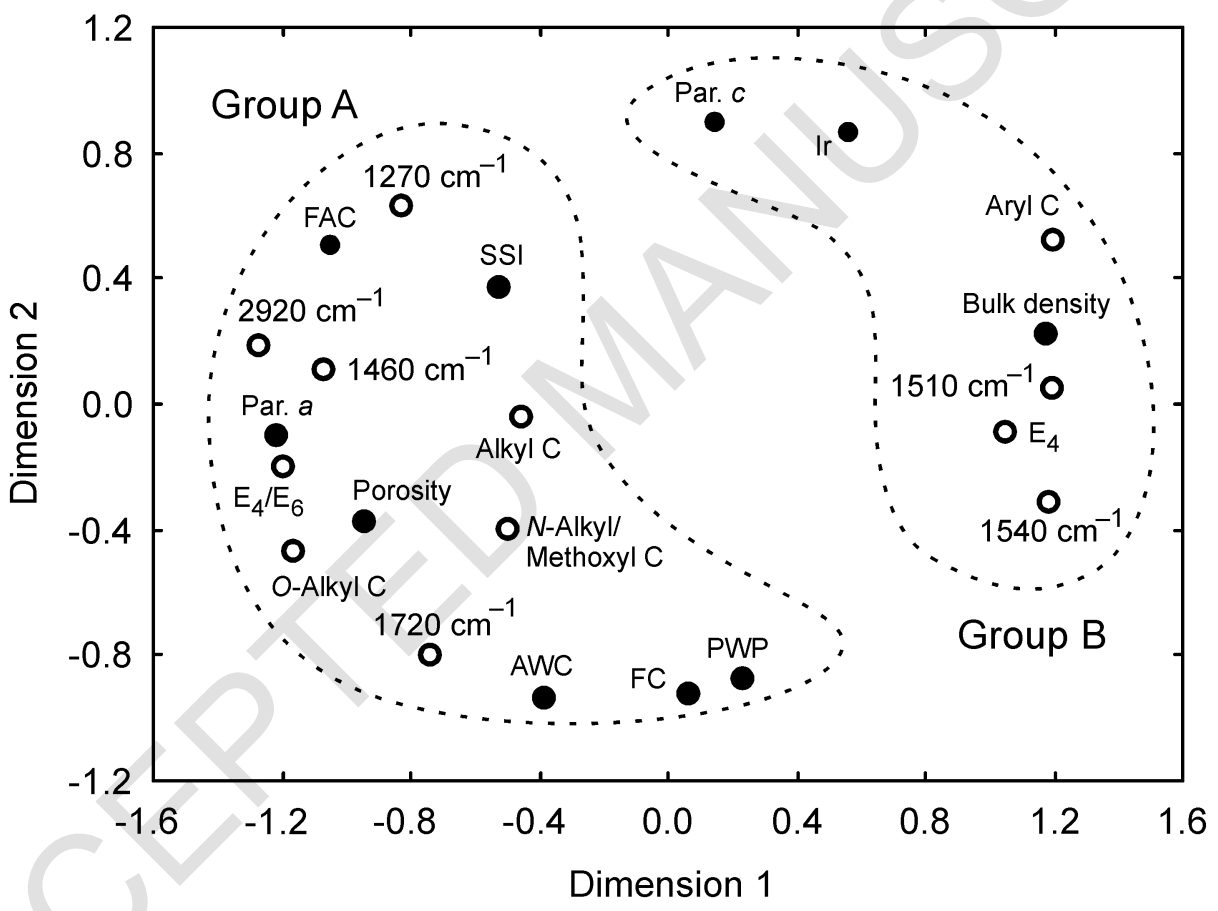

